Increasing soil age drives shifts in plant-plant interactions from positive to negative and affects primary succession dynamics in a subalpine glacier forefield

\title{
Song, Mengya
}

2019-11-01

Song , M , Yu , L , Jiang , Y , Korpelainen , H \& Li , C 2019 , ' Increasing soil age drives shifts in plant-plant interactions from positive to negative and affects primary succession dynamics in a subalpine glacier forefield ' , Geoderma , vol. 353 , pp. 435-448 . https://doi.org/10.1016/j.geoderma.2

http://hdl.handle.net/10138/332470

https://doi.org/10.1016/j.geoderma.2019.07.029

cc_by_nc_nd

acceptedVersion

Downloaded from Helda, University of Helsinki institutional repository.

This is an electronic reprint of the original article.

This reprint may differ from the original in pagination and typographic detail.

Please cite the original version. 
Increasing soil age drives shifts in plant-plant interactions from positive to negative and affects primary succession dynamics in a subalpine glacier forefield

9 a Key Laboratory of Geospatial Technology for the Middle and Lower Yellow River Regions,

10 College of Environment and Planning, Henan University, Kaifeng 475004, Henan, China

$11{ }^{\mathrm{b}}$ College of Life and Environmental Sciences, Hangzhou Normal University, Hangzhou 310036,

12 Zhejiang, China

$13{ }^{\mathrm{c}}$ Department of Agricultural Sciences, Viikki Plant Science Centre, University of Helsinki, P.O. Box

$14 \quad 27$, FI-00014, Finland

$15{ }^{*}$ Corresponding author: Chunyang $\mathrm{Li}$

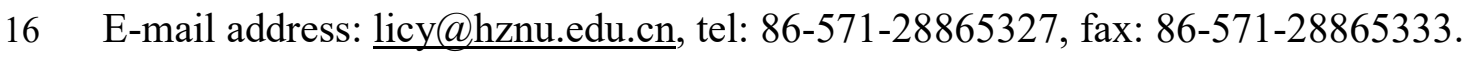

\section{Highlights}

19 - Facilitation frequently occurring in subalpine environments promotes survival.

20 - Populus-Salix interplay switches from positive to negative during primary succession.

21 - Soil age regulates plant-plant interactions in a subalpine glacier forefield.

22 - Nitrogen availability mediates plant-soil feedbacks between neighboring plants. 
Abstract The stress gradient hypothesis predicts that plant-plant interactions switch between facilitation (positive) and competition (negative) along environmental gradients, with facilitation being more common under high abiotic stress conditions relative to more moderate abiotic stress conditions. Our aim was to reveal, whether the interactions between Populus purdomii Rehder and Salix rehderiana Schneider switch from positive to negative during the early stages of primary succession in the Gongga Mountain glacier retreat region. We also investigated, whether soil age is analyzed differences between intraspecific interactions and interspecific interactions of Populus and Salix under 20- and 40-year-old soil conditions, including plant biomass accumulation and allocation, nutrient absorption and utilization, relative competition intensity, non-structural carbohydrates, foliar carbon and nitrogen isotope composition, mesophyll cell ultrastructure, soil microbial biomass and community structure, extracellular enzyme activities, and soil organic carbon (SOC), soil total nitrogen $(\mathrm{TN})$, soil ammonium $\left(\mathrm{NH}_{4}{ }^{+}-\mathrm{N}\right)$, and soil nitrate $\left(\mathrm{NO}_{3}{ }^{-} \mathrm{N}\right)$ contents. We found that $P$. purdomii and S. rehderiana growing under interspecific interactions had greater contents of aboveground dry matter, belowground dry matter and total dry matter compared to intraspecific interactions in 20-year-old soil. Furthermore, in 40-year-old soil conditions, the phospholipid fatty acid (PLFA) analysis showed that Populus and Salix exposed to interspecific interactions exhibited lower amounts of gram-positive bacteria, fungi $(18: 1 \omega 9 \mathrm{c})$ and actinomycetes, and lower levels of total PLFAs than those growing under intraspecific interactions. The redundancy analysis (RDA) results demonstrated that soil $\mathrm{N}$ was the most important parameter contributing to the composition of microbial communities. In addition, the ${ }^{15} \mathrm{~N}$ stable isotope labeling method showed that Populus and Salix growing under interspecific interactions had higher foliage $\delta^{15} \mathrm{~N}$ 
45 derived from $\mathrm{NO}_{3}{ }^{-}\left(\delta^{15} \mathrm{~N}_{-} \mathrm{NO}_{3}{ }^{-}\right)$than those growing under intraspecific interactions in 20-year-old 46 soil. In summary, our results demonstrated that Populus-Salix interactions exhibited positive effects

47 on survival in 20-year-old soil. Conversely, under 40-year-old soil conditions, Populus-Salix 48 interactions presented negative effects in relation to nutrients and elimination by neighboring plants.

49 Moreover, soil age is a major driving factor for plant-plant interactions that shift from positive to 50 negative with an increasing soil age in the Gongga Mountain glacier retreat area. In all, our results 51 support the stress gradient hypothesis. Our findings improve understanding of plant-plant 52 interactions and plant-soil feedbacks during the early stages of soil development, and of the 53 construction of vegetation communities.

55 Keywords: Plant-plant interactions; Positive and negative effects; ${ }^{13} \mathrm{C}$ and ${ }^{15} \mathrm{~N}$ stable isotope 56 composition; Microbial community structure; Primary succession; Glacier retreat area. 


\section{Introduction}

59 The stress gradient hypothesis (SGH) predicts that the dynamic balance between facilitation and 60 competition varies along environmental gradients, with facilitation dominating under high 61 environmental stress and competition under low environmental stress (Bertness and Callaway, 1994; Travis et al., 2006; He et al., 2013). Experiments that have provided support for the stress gradient hypothesis have demonstrated that the impact of facilitation increases relative to competition with increasing abiotic stress (Callaway et al., 2002; Dohn et al., 2013; Michalet et al., 2014). Switching between facilitation and competition could be primarily attributed to changes in external abiotic and biotic conditions (e.g., changes in light, water, space, temperature, soil quality and nutrient availability).

Plant-plant competitive interactions influence plant growth, distribution and abundance, species coexistence, and the composition of plant communities in terrestrial ecosystems (Connell, 1983; Choler et al., 2001; Brooker, 2006). Recent studies have focused on plant-plant facilitative interactions that regulate individual fitness, species composition and diversity, and vegetation community structures, particularly those in alpine ecosystems (Lin et al., 2012; Arroyo et al., 2015; Kéfi et al., 2016; Qi et al., 2018). Some studies have shown that facilitative interactions mainly occur at high elevations and under high biotic and abiotic environmental stress conditions (Choler et al., 2001; Bruno et al., 2003; Kikvidze et al., 2006). Competition and facilitation are major drivers of plant community structure and composition, as well as plant species dynamics (Fowler, 1986;

78 Choler et al., 2001). 
80 Morphological and physiological traits respond to plant-plant interactions (positive or negative), as

81 well as soil carbon:nitrogen $(\mathrm{C}: \mathrm{N})$ and nitrogen:phosphorus $(\mathrm{N}: \mathrm{P})$ ratios, with repercussions on soil 82 microbial communities and soil fertility (Huston and DeAngelis, 1994; Callaway et al., 1997; 83 Zechmeister-Boltenstern et al., 2015). Jiang et al. (2018) showed that the leaf N:P ratio increased phosphorus. Plants have developed different physiological responses to environmental stresses (such as drought, nutrient deficiency or competition): they perceive and transmit stress signals, as well as regulate morphology and physiological properties (Chen et al., 2010; Zhang et al., 2014; Chen et al., 2015). Furthermore, aboveground and belowground subsystems and their feedbacks are important processes for studying the relationships of neighboring plants (Wardle et al., 2004; Ushio et al., 2016).

Plant-soil microbes associations are an important link between aboveground and belowground subsystems. For instance, plant residues (e.g., leaf litter, woody debris and dead roots) affect microbial activities and serve as a major source of carbon and nutrients for microbial decomposer communities (Chapin et al., 1994; Kaye et al., 1997; van der Heijden et al., 2003). Meanwhile, the chemical composition of plant residues affects microbial activities and community structures and, in turn, soil microorganisms are primary decomposers of dead plant material and they influence plants' nutritional quality (Aneja et al., 2006; Göransson et al., 2011). Aboveground and belowground interactions drive the structure and functioning of ecosystems, including carbon and nutrient cycling (Kardol and Wardle, 2010). 
102 During primary succession in a glacier forefield, changes in the biochemical properties of soil (e.g., 103 increasing nutrient availability and accumulation of organic matter) and in the composition of 104 microbial communities influence plant growth and performance traits (Hodkinson et al., 2003; 105 Walker et al., 2010; Castle et al., 2016). Nutrient resources are limited during the early stages of 106 primary succession (He and Tang, 2008; Göransson et al., 2011). Low nutrient availability 107 frequently limits plant growth and competitive ability, particularly in cold ecosystems, such as 108 alpine or subalpine environments, where low temperature restricts underground decomposition 109 processes of soil organic matter (Chapin and Shaver, 1985; Nadelhoffer et al., 1991; Robinson et al., 110 1995). The decomposition of plant litter is closely related to soil nutrient ( $\mathrm{N}$ and $\mathrm{P}$ ) contents, and 111 soil microbes are crucial for plant litter decomposition (Fujii and Takeda, 2010; Zhao et al., 2013; 112 Zechmeister-Boltenstern et al., 2015).

114 Primary succession in the Gongga Mountain glacier forefield has resulted in the establishment of 115 following predominant plant populations: bare land, Astragalus mahoshanicus and Epilobium 116 amurense herb vegetation, Hippophaer hamnoides and Salix rehderiana sapling scrub forest, Salix 117 rehderiana and Populus purdomii deciduous broad-leaved forest, Betulautilis and Rhododendron 118 simsii evergreen broad-leaved forest, and Abies fabri and Picea brachytyla evergreen coniferous 119 forest (Zhou et al., 2013; Lei et al., 2015). During primary succession, S. rehderiana initially 120 appears, then $P$. purdomii, and later, $P$. purdomii replaces $S$. rehderiana as the dominant trees in the 121 community, followed by multiple interactive relationships between $P$. purdomii and S. rehderiana. 122 Soil nitrogen, which plays a key role in plant growth, is limited during the early primary succession 
123 (Chapin et al., 1994; He and Tang, 2008). Previous studies have shown that litter decomposition by

$124 \mathrm{~N}$-fixing species contributes to the accumulation of soil $\mathrm{N}$ during succession, with the topsoil having 125 the highest amounts of nutrients (Jia et al., 2005). Song et al. (2017) showed that N-addition could 126 regulate changes in the competitive ability between $P$. purdomii and S. rehderiana. However, our 127 understanding of the major effects of soil age on plant-plant interactions and plant-soil feedbacks 128 during soil development and primary succession in a glacial forefield, especially considering 129 climate warming, is limited.

131 In the present study, we examined the relationship between $P$. purdomii and $S$. rehderiana 132 individuals (e.g., from positive to negative, from negative to positive, or no change) along with 133 aging soil under intra- and interspecific interactions in the Gongga Mountain glacier retreat area. 134 Moreover, soil microbial community structures and soil nutrient availabilities were measured in 135 order to elucidate the mechanism of the switch between facilitation and competition. We hypothesized the following: 1) plant-plant interactions predominantly show facilitation in severe 137 environments during the early stages of primary succession in subalpine glacier retreat areas, 138 whereas under relatively benign nutrient conditions, the interactions between neighboring plants 139 change into competition; 2) the composition of soil microbes and nutrient abundance are the main 140 driving forces for the shift of Populus-Salix interactions from positive to negative with increasing 141 soil age. To validate these hypotheses, we examined a set of morphological and physiological 142 indexes of plants, soil microbial biomass and community composition, extracellular enzyme 143 activities, and nutrient availability. 


\section{Materials and methods}

\subsection{Study site}

The experiment was conducted at the Gongga Mountain Alpine Ecosystem Observation and 150 Experiment Station of the Chinese Academy of Sciences (29³4' N, 101 $59^{\prime}$ E, 3,000 m a.s.1.), 151 located on the south-eastern fringe of the Tibetan Plateau (Fig. 1). The mean annual temperature is $4.2^{\circ} \mathrm{C}$, mean annual precipitation is approximately $1,949 \mathrm{~mm}$ (rainfall mainly occurring from June to September), and mean annual air relative humidity is about 90.2\% (Yang et al., 2014). The 154 Hailuogou glacier is one of the most representative monsoonal temperate valley glaciers. Its length is around 2,000 m, width about 50-200 $\mathrm{m}$ and elevation between 2,850-3,000 $\mathrm{m}$ (He and Tang, 2008; Liu et al., 2010). It is located on the eastern slope of the Gongga Mountain, with a glacier area of approximately $25 \mathrm{~km}^{2}$ (Liu et al., 2010). During recent years, the Hailuogou glacier has decreased in size due to climate warming. During the past 120 years, the glacier retreat area has undergone a long-term primary succession from pioneer species to an evergreen coniferous forest following a chronosequence of soil development. Previously, this glacier forefield has been utilized when studying primary succession, soil formation processes, plant-soil feedbacks and plant-plant interactions (Wang et al., 2016; Song et al., 2017; Jiang et al., 2018; Jiang et al., 2019).

\subsection{Plant materials and experimental design}

166 Current season seedlings of $P$. purdomii and $S$. rehderiana were selected from the nursery 
surrounding the station in September 2014. A total of 72 seedlings were collected (36 of each species). The seedlings had uniform basal stem diameter (about $3.5 \mathrm{~mm}$ ) and height (about $15 \mathrm{~cm}$ ). Two seedlings (situated $10 \mathrm{~cm}$ apart) were planted into a plastic pot (internal diameter: $30 \mathrm{~cm}$; height: $25 \mathrm{~cm}$ ) with 20- and 40-year-old soil (two seedlings per pot; two seedlings of $P$. purdomii or S. rehderiana, or one P. purdomii and one S. rehderiana). The 20- and 40-year-old soils used in the experiments were collected from the topsoil $(0-15 \mathrm{~cm})$ in the glacier retreat area. The $20-$ and 40-year-old soils had soil organic carbon contents of $11.81 \mathrm{~g} \cdot \mathrm{kg}^{-1}$ and $16.59 \mathrm{~g} \cdot \mathrm{kg}^{-1}$, total nitrogen of $0.34 \mathrm{~g} \cdot \mathrm{kg}^{-1}$ and $0.54 \mathrm{~g} \cdot \mathrm{kg}^{-1}$, total phosphorus of $0.34 \mathrm{~g} \cdot \mathrm{kg}^{-1}$ and $0.29 \mathrm{~g} \cdot \mathrm{kg}^{-1}$, and total potassium of

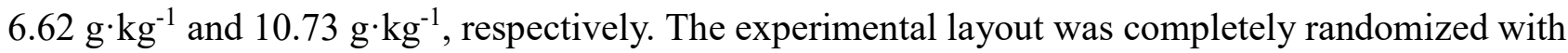
three factors (species, soil age and planting pattern). Experiments with two species (P. purdomii and S. rehderiana), two soil ages (20 and 40 years old), and three planting patterns (P. purdomii and $P$. purdomii intraspecific treatment; $S$. rehderiana and $S$. rehderiana intraspecific treatment; and $P$. purdomii and S. rehderiana interspecific treatment) were established (Fig. S1). Six replicates per treatment were included in the study. The experiments were performed on an open site in the field under natural rain conditions. Furthermore, we used the ${ }^{15} \mathrm{~N}$ isotope tracer method to study differences in the absorption and utilization of $\mathrm{N}$ forms $\left(\mathrm{NH}_{4}{ }^{+}\right.$and $\left.\mathrm{NO}_{3}{ }^{-}\right)$in P.purdomii and $S$. rehderiana individuals. The ${ }^{15} \mathrm{~N}$ tracer solution, with labelled ${ }^{15} \mathrm{NH}_{4} \mathrm{NO}_{3}$ and $\mathrm{NH}_{4}{ }^{15} \mathrm{NO}_{3}$, was injected into the soil at a depth of $5 \mathrm{~cm}$ around the plants $\left(30 \mathrm{mg}{ }^{15} \mathrm{NH}_{4}{ }^{+}-\mathrm{N}\right.$ per plant or $30 \mathrm{mg}$ ${ }^{15} \mathrm{NO}_{3}{ }^{-}-\mathrm{N}$ mg per plant). Then, $72 \mathrm{~h}$ after the application of the ${ }^{15} \mathrm{~N}$ solution, the plants were harvested and foliage ${ }^{15} \mathrm{~N}$ values were determined (Chen et al., 2014). 
190 Four pots from six replicates were randomly harvested at the end of the experiment on August 25,

191 2015. All individuals were sorted into roots, stems and leaves, and all biomass samples were dried $192\left(70^{\circ} \mathrm{C}, 72 \mathrm{~h}\right)$ to a constant weight to measure aboveground, belowground, and total dry matter 193 accumulation. The root to shoot $(\mathrm{R} / \mathrm{S})$ ratios were calculated. Dried leaf and root samples were 194 ground to a fine powder and were passed through a mesh (pore diameter: $250 \mu \mathrm{m}$ ). Then, the $\mathrm{C}, \mathrm{N}$ 195 and $\mathrm{P}$ contents of these tissues were measured by the rapid dichromate oxidation technique (Nelson 196 and Sommers, 1982), the semi-micro Kjeldahl method (Fawcett, 1954), and induced plasma 197 emission spectroscopy (Parkinson and Allen, 1975), respectively.

199 Non-structural carbohydrates of the root and leaf tissues were estimated as starch, soluble sugar, 200 fructose, and sucrose contents. Approximately $50 \mathrm{mg}$ of each dry powdered plant sample was mixed 201 with $6 \mathrm{~mL}$ of $80 \%(\mathrm{v} / \mathrm{v})$ ethanol, incubated for $30 \mathrm{~min}$ in a water bath at $80^{\circ} \mathrm{C}$, then centrifuged for 5 min at 7,000 $g$ (Guo et al., 2016; Song et al., 2017). The ethanol extract solution was used for the determination of the fructose content according to a modified resorcinol method (Murata et al., 1968), the sucrose content was measured according to the procedure of Green et al. (1994), and the total soluble sugar content was measured according to the anthrone-sulfuric acid method (Yemm and Willis, 1954). The solid residue was hydrolyzed with $2 \mathrm{~mL}$ of $9.2 \mathrm{~mol} \cdot \mathrm{L}^{-1} \mathrm{HClO}_{4}$ for $30 \mathrm{~min}$ to measure the starch content (Yemm and Willis, 1954). 
211 Stable isotope analyses were performed at the Stable Isotope Laboratory, Chinese Academy of 212 Forestry, using a DELTA V Advantage Isotope Ratio Mass Spectrometer (Thermo Fisher Scientific, 213 Inc., Waltham, MA, USA). The carbon isotope composition $\left(\delta^{13} \mathrm{C}\right)$ was used to estimate long-term 214 tree water use efficiency (Dong et al., 2015). The $\delta^{13} \mathrm{C}$ value of the samples was expressed relative 215 to the standard Pee Dee Belemnite (Farquhar et al., 1989) as follows: $\delta^{13} \mathrm{C}(\%)=\left(R_{\text {sample }} / R_{\text {standard }}-1\right)$ $216 \times 1,000$, where $R_{\text {sample }}$ is the ${ }^{13} \mathrm{C} /{ }^{12} \mathrm{C}$ ratio of the sample, and $R_{\text {standard }}$ is that of the standard substance. 217 The ${ }^{15} \mathrm{~N}$ concentration values were converted to $\delta^{15} \mathrm{~N}$ using the following equation: $\delta^{15} \mathrm{~N}(\%)=$ $218\left(T_{\text {sample }} / T_{\text {standard }}-1\right) \times 1,000$, where $T_{\text {sample }}$ is the ${ }^{15} \mathrm{~N} /{ }^{14} \mathrm{~N}$ ratio of the sample, and $T_{\text {standard }}$ is that of the 219 standard substance. The overall precision of the $\delta^{13} \mathrm{C}$ and $\delta^{15} \mathrm{~N}$ estimations was better than $0.1 \%$, as 220 determined from four replicates in each case.

\subsection{Leaf ultrastructural assessment}

Mesophyll cell observations are widely used to investigate changes in leaf organelles under various abiotic stresses (e.g., competitive pressure or nutrient deficiency). Sections ( $2 \mathrm{~mm}$ in length) from middle leaf parts were selected for transmission electron microscopy (TEM) analyses according to the procedures of Zhao et al. (2009) and Song et al. (2017). In brief, the sections were fixed in 3\% glutaraldehyde (v/v) in $0.2 \mathrm{M}$ sodium phosphate buffer $(\mathrm{pH} 7.2)$ for $6-8 \mathrm{~h}$, post-fixed in $1 \%$ osmium tetroxide for $1 \mathrm{~h}$, and finally, again, in $0.2 \mathrm{M}$ sodium phosphate buffer $(\mathrm{pH} 7.2)$ for $1-2 \mathrm{~h}$. Ultrathin sections ( $80 \mathrm{~nm}$ thick) were sliced, stained with uranyl acetate and lead citrate, and mounted on copper grids for viewing on H-600IV TEM (Hitachi, Tokyo, Japan). 
235 Four soil samples from each treatment were randomly selected at the end of the experiment to 236 analyze soil biochemical properties and microbial community structures. Topsoil samples were 237 collected from depths of $0-15 \mathrm{~cm}$ around the seedlings, immediately transported to the laboratory for 238 further analysis and stored at $4{ }^{\circ} \mathrm{C}$ for a later assessment of microbial biomass and enzyme activities, 239 and at $-20{ }^{\circ} \mathrm{C}$ for a subsequent phospholipid fatty acid analyses (performed within one week). The 240 moist soil samples were sieved (pore size: $2 \mathrm{~mm}$ ) to remove large organic debris prior to analyses. 241 The remaining soil samples were air-dried at room temperature and used for the determination of 242 chemical properties.

244 Soil organic $\mathrm{C}$ concentrations were measured using the potassium dichromate oxidation-ferrous 245 sulfate titrimetry method (Nelson and Sommers, 1982). Total N concentrations were determined 246 using a LECO EPS-2000 CNS thermal combustion furnace (LECO Corp., St Jose, MI). Total P was 247 melted by sodium carbonate, and determined by molybdenum-blue colorimetry. Total potassium (K) 248 was digested by $\mathrm{HF}-\mathrm{HClO}_{4}$ and detected by flame photometry. Alkali-hydrolyzable $\mathrm{N}$ was extracted 249 with $2 \mathrm{M} \mathrm{KCl}$ and measured using a microplate reader (Biotek, Winooski, USA). Available P was 250 extracted with $0.5 \mathrm{M} \mathrm{NaHCO}_{3}$ and determined using the molybdenum blue method. Available $\mathrm{K}$ 251 was extracted with $1 \mathrm{M}$ ammonium acetate and quantified by flame photometry (FP640, INASA, 252 China). Soil $\mathrm{pH}$ was determined using a 1:2.5 ratio of soil (in grams) to water (in milliliters) using a pH electrode (FE20, Mettler Toledo, Switzerland). Ammonium $\left(\mathrm{NH}_{4}{ }^{+}-\mathrm{N}\right)$ and nitrate $\left(\mathrm{NO}_{3}{ }^{-}-\mathrm{N}\right)$ were 
biomass carbon $(\mathrm{MBC})$ and nitrogen $(\mathrm{MBN})$ were measured using fresh soil and the chloroform fumigation-extraction method (Brookes et al. 1985; Vance et al. 1987) with a Multi-N/C2100 analyzer (Analytik Jena, Germany). MBC and MBN were calculated from the differences between extractable $\mathrm{C}$ and $\mathrm{N}$ concentrations in fumigated and unfumigated samples using conversion factors

259 ( $\mathrm{k}_{\mathrm{EC}}$ and $\mathrm{k}_{\mathrm{EN}}$ ) of 0.45 for both (Vance et al. 1987). The urease activity was measured by colorimetry according to the method of Kandeler and Gerber (1988) and was expressed as $\mu \mathrm{g} \mathrm{NH} 4-\mathrm{N} \cdot \mathrm{g}^{-1} \cdot \mathrm{soil}^{-1} \cdot \mathrm{h}^{-1}$.

The nitrate reductase activity was determined using the colorimetric method (Kandeler, 1996) and was expressed as $\mu \mathrm{g} \mathrm{NO}_{2}-\mathrm{N} \cdot \mathrm{g}^{-1} \cdot \mathrm{soil} \cdot \mathrm{h}^{-1}$. The saccharase activity was determined with a spectrophotometer (U-2800, Japan) at a wavelength of $508 \mathrm{~nm}$ by the method described by Guan 264 (1986) and was expressed as $\mu$ g glucose $\cdot \mathrm{g}^{-1} \cdot \mathrm{soil} \cdot \mathrm{h}^{-1}$.

\subsection{Phospholipid fatty acid extraction and analysis}

The composition of soil microbial communities was assessed by the PLFA analysis using a modified method of Frostegård et al. (1991), as described by Xu et al. (2015) and Duan et al. (2015). Briefly,

$6 \mathrm{~g}$ of frozen soil was extracted with a chloroform:methanol:citrate acid buffer mixture (1:2:0.8, $\mathrm{v} / \mathrm{v} / \mathrm{v})$. The lipids were separated into neutral lipids, glycolipids, and phospholipids on silicic acid columns. The phospholipids were subjected to mild alkaline methanolysis (Schindlbacher et al., 2011). The extracted fatty acid methyl esters were analyzed using a Hewlett-Packard 6890 gas

274 chromatograph with an Ultra 2-HP capillary column (cross-linked with 5\% phenyl-methyl silicone; $27525 \mathrm{~m}, 0.22 \mathrm{~mm}$ ID, and $0.33 \mu \mathrm{m}$ thickness). The peaks were identified using bacterial fatty acids as standards and utilizing the Sherlock peak identification software (MIDI, Inc. Newark, DE, USA). 
277 Fatty acids were quantified through a comparison of the sample peak areas with those of internal standards (19:0 nonadecanoic methyl ester) (Smithwick et al., 2005). The areas measured by

279 GC-FID were used to calculate the abundance of PLFA markers, which were expressed as 280 nmol·PLFA g ${ }^{-1}$ dry soil (Schindlbacher et al., 2011). We used the terminal-branched saturated PLFA 281 peaks i14:0, a15:0, i15:0, i15:0 G, i16:0, i17:0, and a17:0 as markers for gram-positive $(\mathrm{G}+)$ bacteria

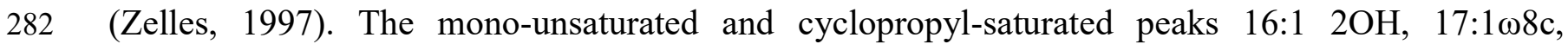

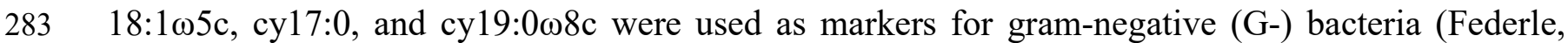

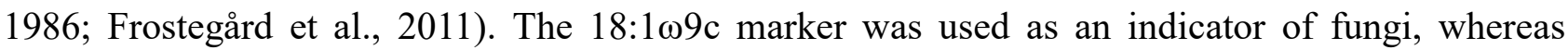

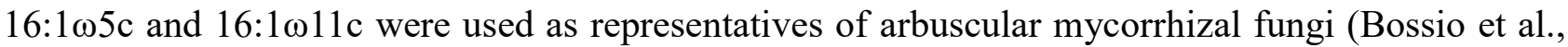
1998; Swallow et al., 2009; Huang et al., 2013; Xu et al., 2015). The PLFA peaks 10 Me17:0 and 10 Me18:0 were selected as indicators of actinomycetes (Waldrop et al., 2004).

2.8. Data analyses

The experimental layout was completely randomized with three factors (species, planting pattern and soil age). Experiments with P. purdomii and S. rehderiana were established to test intraspecific interactions (two of the same species per mesocosm) or interspecific interactions (two different species per mesocosm) in soil of two ages (20 and 40 years old). We calculated the relative competition intensity (RCI) of both $P$. purdomii and $S$. rehderiana when subjected to different planting patterns and soil ages, according to the formula described by Grace (1995) and Guo et al. 297 (2017) as follows: $\mathrm{RCI}=\left(\mathrm{B}_{\mathrm{m}}-\mathrm{B}_{\mathrm{n}}\right) / \mathrm{B}_{\mathrm{n}}$, where $\mathrm{B}_{\mathrm{m}}$ represents the dry biomass matter of one seedling 298 from interspecific planting and $\mathrm{B}_{\mathrm{n}}$ represents the average dry biomass matter of corresponding 
299 plants from intraspecific planting. If the RCI value is positive, the interspecific interaction has a 300 facilitative effect on the species, while if the RCI value is negative, the interspecific interaction has 301 a competitive effect on the species. Statistical analyses were conducted with the SPSS 16.0 for 302 Windows statistical software package (SPSS, Chicago, IL, USA). Individual differences among 303 treatments were compared by Tukey's tests following one-way ANOVAs. In addition, Generalized 304 Linear Model was performed using the R statistical software (version 3.3.2) to evaluate the effects 305 of species, soil age, planting pattern, and their interactions on each variable. All statistical tests were 306 considered significant at $P<0.05$. Redundancy analysis (RDA) was further undertaken to visualize 307 the relationship between soil microbial community composition and soil properties (soil organic C, 308 biochemical parameters, and enzyme activities), performed using Canoco 5.0 (Microcomputer 309 Power, Ithaca, NY, USA). 


\section{Results}

3.1. Effects of soil age and plant-plant interactions on morphological and physiological

characteristics

In 20-year-old soil conditions, S. rehderiana individuals exhibited significantly higher aboveground dry matter (ADM), belowground dry matter (BDM) and total dry matter (TDM) weights when grown under interspecific interactions compared to intraspecific conditions (Fig. 2). However, in 40-year-old soil conditions, P. purdomii individuals showed significantly lower ADM, BDM and TDM under interspecific growth conditions when compared to intraspecific treatments (Fig. 2). On the other hand, S. rehderiana individuals from interspecific interactions showed lower ADM, BDM and TDM in 40-year-old soil compared to the values detected in 20-year-old soil. Furthermore, no significant differences were observed in the $\mathrm{R} / \mathrm{S}$ ratio of $P$. purdomii and $S$. rehderiana between interspecific and intraspecific conditions in 20-year-old soil, whereas a significantly lower R/S ratio was detected in 40-year-old soil (Fig. 2d). In 20-year-old soil conditions, the relative competition intensity (RCI) value of $P$. purdomii and S. rehderiana was positive, which indicated that there was a cooperative relationship between the two species. However, in 40-year-old soil conditions, the RCI value of $P$. purdomii was negative, which indicated that $P$. purdomii was inhibited by competitive stress caused by $S$. rehderiana (Fig. 3). The growth traits of seedling (ADM, BDM and TDM) were significantly affected by species, soil age, species $\times$ soil age, species $\times$ planting pattern, and soil age $\times$ planting pattern (Table 4 ). 
343 In 20-year-old soil conditions, $P$. purdomii individuals subjected to interspecific interactions showed 344 significantly higher leaf and root starch contents than those exposed to intraspecific interactions, 345 whereas $S$. rehderiana showed no significant differences in starch contents (Fig. 4a). P. purdomii 346 individuals subjected to interspecific treatments had significantly higher leaf and root starch 347 contents than those under intraspecific planting conditions, whereas S. rehderiana plants presented 348 significantly lower leaf starch contents under interspecific planting than those subjected to 349 intraspecific interactions when grown in 40-year-old soil (Fig. 4a). Under 20-year-old soil and 350 interspecific growth conditions, $P$. purdomii individuals exhibited significantly higher root total 351 sugar contents compared to those under intraspecific planting, whereas when grown in 40-year-old 352 soil conditions, $P$. purdomii individuals growing under interspecific competition showed 353 significantly lower root total sugar contents than those under intraspecific interactions (Fig. 4b). $P$. 354 purdomii plants from intraspecific interactions exhibited significantly lower fructose and sucrose 355 contents when grown in 40-year-old soil compared to those grown in 20-year-old soil (Fig. 4c and d). The interaction of species $\times$ soil age, species $\times$ planting pattern and species $\times$ soil age $\times$ planting 357 pattern significantly affected leaf starch, while root starch was significantly affected by species, soil 358 age, planting pattern, species $\times$ soil age and species $\times$ planting pattern (Table 4).

3.2. Effects of soil age and plant-plant interactions on nutrient absorption and allocation, and on foliage $C$ and $N$ isotopic composition

P. purdomii and S. rehderiana exhibited higher $\mathrm{N}$ and $\mathrm{P}$ contents but lower $\mathrm{C}: \mathrm{N}$ ratios in leaves than in roots (Fig. 5). In 20-year-old soil conditions, S. rehderiana experiencing interspecific interactions 
365 showed significantly higher leaf $\mathrm{N}$ contents than plants grown under intraspecific planting, whereas 366 no significant differences in leaf $\mathrm{N}$ contents were observed in $P$. purdomii. The root $\mathrm{N}$ content of $P$. 367 purdomii under interspecific planting was significantly higher in 40-year-old soil compared to that 368 in 20-year-old soil. P. purdomii and S. rehderiana individuals exposed to interspecific interactions in 369 20-year-old soil showed higher root C:N ratios than those subjected to intraspecific conditions (Fig. 370 5c). S. rehderiana plants subjected to interspecific planting had higher leaf N:P ratios than those 371 under intraspecific interactions in 20-year-old soil (Fig. 5d). Using a combination of 40-year-old 372 soil and interspecific conditions, $S$. rehderiana plants exhibited lower root C:N ratios than those 373 subjected to intraspecific treatment (Fig. 5c). The interaction of species $\times$ planting pattern, soil age $374 \times$ planting pattern, and species $\times$ soil age $\times$ planting pattern significantly affected leaf $\mathrm{N}$ contents 375 and leaf $\mathrm{C}: \mathrm{N}$ radio. Root $\mathrm{N}$ contents and root $\mathrm{C}: \mathrm{N}$ ratio were significantly affected by soil age, planting pattern, species $\times$ soil age, and soil age $\times$ planting pattern $($ Table 4$)$.

Under 20- and 40-year-old soil conditions, P. purdomii and S. rehderiana subjected to interspecific treatments had lower levels of $\delta^{15} \mathrm{~N}$ derived from $\mathrm{NH}_{4}{ }^{+}\left(\delta^{15} \mathrm{~N}-\mathrm{NH}_{4}{ }^{+}\right)$than those growing under intraspecific conditions (Fig. 6a). P. purdomii and S. rehderiana exposed to interspecific treatments 381 exhibited higher levels of $\delta^{15} \mathrm{~N}$ derived from $\mathrm{NO}_{3}^{-}\left(\delta^{15} \mathrm{~N}_{-} \mathrm{NO}_{3}{ }^{-}\right)$than plants grown under intraspecific conditions in 20-year-old soil (Fig. 6b). Under 40-year-old soil and interspecific conditions, the $\delta^{15} \mathrm{~N}_{-\mathrm{NO}_{3}}^{-}$level of $S$. rehderiana significantly decreased compared to plants subjected to intraspecific interactions (Fig. 6b). In all treatments, $P$. purdomii individuals presented significantly higher $\delta^{13} \mathrm{C}$ than $S$. rehderiana, whereas $S$. rehderiana individuals exposed to intraand interspecific treatments exhibited no significant differences in $\delta^{13} \mathrm{C}$. When using 40 -year-old 
387 soil, P. purdomii plants that experienced interspecific planting had significantly lower $\delta^{13} \mathrm{C}$ than 388 those exposed to intraspecific interactions (Fig. 6c).

\subsection{Changes in leaf ultrastructure due to soil age and plant-plant interactions}

When using 20-year-old soil, P. purdomii plants exposed to interspecific treatments showed smoother and thicker cell membranes and cell walls than those grown under intraspecific interactions (Fig. 8a and c). In addition, S. rehderiana plants that underwent interspecific treatments were characterized by fewer plastoglobuli and smaller starch granules than those subjected to intraspecific interactions (Fig. $8 \mathrm{~b}$ and d). Under 40-year-old soil conditions, P. purdomii and $S$. rehderiana exposed to interspecific treatments presented negative plant-plant interactions, as indicated by fewer mitochondria, larger plastoglobuli and developing plasmolysis compared to intraspecific treatments (Fig. 8e-h). However, in 20-year-old soil conditions, P. purdomii and $S$. rehderiana grown under interspecific conditions were clearly influenced by positive plant-plant interactions, as indicated by typical chloroplast structures and well-arranged thylakoid membranes, and thick and continuous cytomembranes and cytoderms (Fig. 8a and b). In 40-year-old soil conditions, P. purdomii plants subjected to intraspecific treatments showed higher numbers of 404 mitochondria with a normal structure and clear cristae, whereas $P$. purdomii plants exhibited more 405 severe damage under interspecific planting patterns, as indicated by the disappearance of mitochondria, swollen chloroplasts and numerous plastoglobuli (Fig. 8e). 
410 Soil age significantly affected soil organic carbon (SOC), total nitrogen (TN), total potassium (TK), 411 alkali-hydrolyzable nitrogen (AN), available potassium (AK), $\mathrm{pH}$ levels, and soil enzyme activities, 412 whereas different planting patterns showed no differences in SOC, TN, total phosphorus (TP), and $413 \mathrm{pH}$ values (Table 1). P. purdomii and S. rehderiana individuals exposed to interspecific treatments 414 showed higher soil AN contents than those grown under intraspecific interactions in 20-year-old soil. 415 However, in 40-year-old soil conditions, interspecific Populus-Salix plantings showed lower soil TN 416 contents compared to intraspecific conditions. Intra- and interspecific treatments using 40-year-old 417 soil presented higher SOC and TN contents than those using 20-year-old soil. Thus, SOC and TN 418 contents increased with aging soil. Small changes in soil enzyme activities were observed under 419 different planting patterns in the same-age soil. In addition, Populus-Salix interactions resulted in 420 significantly higher soil nitrate reductase activities compared to those of Salix-Salix interactions 421 under 20-year-old soil conditions (Table 1). On the other hand, when using 40-year-old soil, 422 Populus-Salix interactions exhibited significantly lower soil nitrate reductase activities. The 423 activities of soil urease, invertase, and nitrate reductase were significantly higher in 40 -year-old soil 424 than in 20-year-old soil.

\subsection{Soil microbial biomass and community structure characteristics}

Under 20-year-old soil conditions, no significant differences were observed in $\mathrm{MBC}, \mathrm{MBN}$, or in the MBC:MBN ratio among the three planting patterns (interspecific Populus-Salix, intraspecific 
Populus-Salix planting resulted in lower MBC and MBN contents when compared to intraspecific

432 Salix-Salix planting (Table 1). Intraspecific Salix-Salix treatments showed higher MBC and MBN 433 contents in 40-year-old soil than in 20-year-old soil. Also, intraspecific Populus-Populus treatments 434 presented higher MBC and MBN contents in 40-year-old soil than in 20-year-old soil. MBC and 435 MBN contents were higher in 40-year-old soil compared to those in 20-year-old soil, and increasing 436 soil microbial biomass affected plant-soil interactions as well (Table 1). The increase in soil microbial biomass is associated with a series of physicochemical processes between plant and soil. Under 20-year-old soil conditions, the Populus-Salix planting pattern showed no differences in soil microbes, whereas there were differences when 40-year-old soil was used.

No significant differences were observed in the total amounts of PLFAs among planting patterns in 20-year-old soil, whereas in 40-year-old soil, significant differences were observed (Table 2). Furthermore, under 40-year-old soil conditions, interspecific Populus-Salix planting exhibited lower

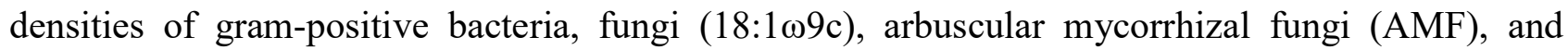
actinomycetes, and lower total PLFA levels when compared to intraspecific planting. Under 20-year-old soil conditions, interspecific planting (PS) showed higher amounts of AMF and fungi $(18: 1 \omega 9 \mathrm{c})$ and higher ratios of gram+/gram- bacteria PLFAs and fungal/bacterial PLFAs when compared to intraspecific planting. However, in 40-year-old soil conditions, interspecific planting (PS) presented significantly lower amounts of AMF and fungi $(18: 1 \omega 9 \mathrm{c})$ and a lower ratio of fungal/bacterial PLFAs compared to intraspecific treatments (PP and SS). In 20-year-old soil under different planting patterns conditions, no significant changes were observed in the community structure of soil microbes, whereas under 40-year-old soil conditions, the effects of interspecific 
Populus-Salix planting were significantly different from those detected in intraspecific treatments. The community structures of soil microbes differed between 40 -year-old soil and 20-year-old soil.

\subsection{Coupling relationship between soil microbes and abiotic factors}

The Pearson correlation analysis on soil microbial communities and abiotic factors indicated that gram-positive bacteria $\left(\mathrm{G}^{+}\right)$and gram-negative bacteria $(\mathrm{G}-)$ were significantly correlated with soil

TN, alkali-hydrolyzable $\mathrm{N}, \mathrm{NH}_{4}{ }^{+}-\mathrm{N}$, and nitrate reductase activity $(P<0.05$, Table 3$)$. The total amounts of PLFAs showed significant positive correlations with $\mathrm{TN}, \mathrm{NH}_{4}{ }^{-}-\mathrm{N}, \mathrm{NO}_{3}{ }^{-}-\mathrm{N}$, and nitrate reductase activity. Soil actinomycetes showed significant positive correlations with SOC, TN, $\mathrm{NH}_{4}{ }^{+}-\mathrm{N}, \mathrm{NO}_{3}{ }^{-}-\mathrm{N}$, and enzyme activities. In addition, $\mathrm{AM}$ fungi exhibited significant positive correlations with $\mathrm{TN}, \mathrm{NH}_{4}{ }^{+}-\mathrm{N}$, and $\mathrm{NO}_{3}{ }^{-}-\mathrm{N}$. Moreover, a significant positive correlation was observed between fungi and alkali-hydrolyzable $\mathrm{N}$ contents. Therefore, the composition of soil microbial communities was largely affected by soil nutrients (particularly N).

Redundancy analysis (RDA) revealed the effects of environmental factors on the composition of correlated with $\mathrm{TN}, \mathrm{AN}, \mathrm{NH}_{4}{ }^{-}-\mathrm{N}, \mathrm{NO}_{3}{ }^{-}-\mathrm{N}$, and nitrate reductase activities. RDA2 was positively correlated with SOC, $\mathrm{pH}$, AP, urease, and saccharase. The analysis included SOC, TN, AN, TP, AP, $473 \mathrm{NH}_{4}{ }^{+}-\mathrm{N}, \mathrm{NO}_{3}{ }^{-}-\mathrm{N}, \mathrm{pH}$, soil urease, saccharase, and nitrate reductase activities as environmental 474 factors. RDA showed that soil AN (which explained $36.8 \%$ of the variance, $P=0.002$ ) was the most important parameter contributing to the composition of soil microbial communities. Thereafter, the 
476 most important ones were soil $\mathrm{NH}_{4}{ }^{+}-\mathrm{N}$ (which explained $33.2 \%$ of the variance, $P=0.002$ ), soil TN 477 (which explained $32.1 \%$ of the variance, $P=0.002$ ), soil saccharase (which explained $29.5 \%$ of the 478 variance, $P=0.002$ ), SOC (which explained $28.3 \%$ of the variance, $P=0.006$ ), soil NRA (which 479 explained $28.2 \%$ of the variance, $P=0.004$ ), soil urease (which explained $25.1 \%$ of the variance, $P$ $480=0.01)$, and soil $\mathrm{NO}_{3}{ }^{-} \mathrm{N}$ (which explained $24.1 \%$ of the variance, $P=0.006$ ). 481 482 483 484 485 486 


\section{Discussion}

500 Plant-plant interactions may induce negative and positive effects on subalpine forest communities.

501 In fact, such negative and positive interactions occur widely in nature, particularly at high altitudes, 502 thereby indicating that plant species are not independently distributed. The stress gradient 503 hypothesis predicts that plant-plant interactions vary along external environmental gradients and 504 that negative interactions are more frequent in relatively productive environments, whereas positive 505 interactions are more common in severe environments (Bertness and Callaway, 1994; He et al., 506 2013). Indeed, many previous studies have shown that plant-plant interactions play a positive role in 507 adaptation to severe environments in terms of survival, whereas neighboring plants undergo 508 competition in low-stress environments to avoid elimination by other species (Callaway and Walker, 509 1997; Fynn et al., 2005; Craine and Dybzinski, 2013). Contrary to facilitative interactions, 510 competitive interactions between neighboring species induce negative interference (Bertness and 511 Callaway, 1994; Brooker and Callaghan, 1998).

513 The present study demonstrated that positive and negative interactions affect the growth traits 514 (biomass allocation, nutrient absorption, mesophyll cells) of $P$. purdomii and $S$. rehderiana 515 individuals in 20- and 40-year-old soil. Furthermore, our data suggested that when soil nutrient 516 resources are limited (e.g., 20-year-old soil), Populus-Salix interactions result in higher above- and 517 belowground dry matter accumulation, foliage starch contents, root $\mathrm{C} / \mathrm{N}$ ratios and $\delta^{15} \mathrm{~N}_{-} \mathrm{NO}_{3}{ }^{-}$ 518 values compared with intraspecific conditions. Thus, there are positive interactions between $P$. purdomii and S. rehderiana individuals when grown in 20-year-old soil. Previous research has 
showed that neighboring plants could improve nutrient availability and micro-climate, which would then ameliorate plant performance under high abiotic stress (Maestre et al., 2005). Conversely, when soil nutrient resources are moderate (e.g., 40-year-old soil), P. purdomii and S. rehderiana subjected to interspecific interactions show a lower rate of dry matter accumulation and lower root/shoot ratios, thus indicating that root growth is inhibited by interspecific competition and there is a negative interaction. In addition, mesophyll cells of $P$. purdomii plants showed tissue damage under interspecific conditions when grown in 40-year-old soil, as indicated by the disappearance of mitochondria, numerous plastoglobuli and developing plasmolysis. As also previously shown, the effect of neighbors is facilitation under low abiotic stress and competition under high stress (Maestre et al., 2005). For instance, Kikvidze et al. (2006) found that plant-plant interactions subalpine plant communities. Moreover, Olsen et al. (2016) showed a temperature-driven switch in plant-plant interactions from facilitation to competition in seminatural grasslands. Our study, which suggests that changes in the level of soil nutrients mediate Populus-Salix interactions from positive to negative in the subalpine glacier retreat areas, provides further support for the results of Brooker and Callaghan (1998) indicating that the intensity of positive interactions increases and that of negative interactions decreases with increasing stress and disturbance.

Plant-soil feedbacks influence plant performance (leaf and root traits) and competitive ability (Kardol et al., 2007; Teste et al., 2017), which could regulate nutrient cycling in ecosystems (Bohlen et al., 2001; Mariotte et al., 2018). Plant growth could change the biochemical properties of soil in a way that affects plant-plant interactions. Our results showed that soil alkali-hydrolyzable $\mathrm{N}$ and 
$542 \mathrm{NO}_{3}{ }^{-}-\mathrm{N}$ contents decrease under interspecific treatment (PS) compared to intraspecific treatments 543 (SS and PP) in 40-year-old soil, whereas in 20-year-old soil, alkali-hydrolyzable $\mathrm{N}$ and $\mathrm{NO}_{3}{ }^{-}-\mathrm{N}$ of 544 PS increase compared to those in SS and PP treatments (Table 1). Soil N gradually accumulates 545 through primary succession, which directly affects the composition of microbial communities and 546 indirectly regulates plant-plant interactions in a glacier forefield. Consequently, plant-soil feedbacks 547 lead to the replacement of early-successional species by late-successional species, as 548 early-successional species suffer from negative plant-soil feedbacks (Kulmatiski et al., 2008). 549 Moreover, our results demonstrated that $\mathrm{SOC}, \mathrm{NH}_{4}{ }^{-}-\mathrm{N}$ and $\mathrm{NO}_{3}{ }^{-}-\mathrm{N}$ contents were significantly 550 higher in 40-year-old soil than in 20-year-old soil, thereby indicating that soil $\mathrm{C}$ and $\mathrm{N}$ contents significantly accumulate in the studied glacier forefield over time. In addition, significantly higher 552 soil enzyme activities were observed in older soil, whereas no differences in enzyme activities in relation to intra- and interspecific interactions were observed, thus indicating that the effects of 554 plant-plant interactions on enzyme activities were relatively small (Table 1). Biochemical properties and extracellular enzyme activities are considered as important indicators of soil fertility 556 (Vepsäläinen et al., 2001; Mairura et al., 2007).

Soil microbes play an important role in the soil development process of primary succession, particularly in glacier retreat regions. Microbes affect plant growth, and feedbacks occur because plants alter microbial communities through root exudates (Westover et al., 1997; Stephan et al., 2000). Wardle et al. (2004) have shown that the decomposer subsystem breaks down dead plant material that indirectly regulates plant growth, and plant litter, in turn, provides energy (C) and nutrients that are required by soil microbes. Moreover, Kardol et al. (2007) have reported that 
564 early-successional plants generally change the composition of soil microbial communities and 565 increase the likelihood for the establishment of mid-successional species. Our findings suggest that 566 under 20-year-old soil conditions, there are no significant differences in the soil microbial biomass 567 and community composition between intra- and interspecific treatments of $P$. purdomii and $S$. 568 rehderiana. However, under 40-year-old soil conditions, interspecific planting of Populus-Salix 569 shows significantly lower amounts of gram-negative bacteria, gram-positive bacteria, AMF, fungi, 570 actinomycetes, and total PLFAs in soil when compared to intraspecific conditions (Table 2). These 571 findings suggest that the composition of soil microbial communities under interspecific conditions 572 substantially differs from that under intraspecific treatments and that belowground competitive interactions decrease soil microbial biomass and change microbial community structures.

The aboveground and belowground linkages have a widely influence on ecosystem processes. The aboveground biota can influence belowground subsystems. As a feedback, belowground organisms could influence plant growth and the structure and function of the aboveground community (Wardle et al., 2004). Plant-soil feedbacks are mechanisms of plant-plant interactions that are dependent on competition for resources and changes in soil properties. Bever et al. (1997) have demonstrated that soil microbes could alter the coexistence of plant species through indirect feedbacks. Furthermore, the composition of soil microbial communities has been shown to have a strong effect on plant-plant interactions, community dynamics and coexistence (Van der Putten and Peters, 1997; Van Der Heijden et al., 2006). Our findings indicate that microbial community compositions (e.g., the amount of PLFAs) have significant correlations with soil $\mathrm{TN}, \mathrm{AN}, \mathrm{NH}_{4}{ }^{+}-\mathrm{N}, \mathrm{NO}_{3}{ }^{-}-\mathrm{N}$ and nitrate reductase activity (Table $3, P<0.05$ ). These results suggest that nitrogen availability in soil is 
586 essential for microbial growth, and it directly affects the growth of plants and the interactions of 587 neighboring plants.

589 Soil microbial effects are incorporated into the dynamic changes of plant communities through 590 niche modification and plant-soil feedbacks (Kardol et al., 2007; Bever et al., 2010). Plant-plant 591 interactions could be directly driven by sharing of resources or competition, and the interactions of 592 plant and soil microbes could mediate the $\mathrm{N}$ transformation process of soil (Bohlen et al., 2001). 593 Göransson et al. (2011) have shown that the availability of resources and nutrient limitation for 594 microbial growth vary along a chronosequence in a glacier forefield, thereby suggesting that 595 microbial growth is mainly limited by $\mathrm{C}$ and plant growth is mainly limited by $\mathrm{N}$, whereas soil 596 microbes are important competitors for $\mathrm{N}$ in young soil. Our results show that soil $\mathrm{N}$ availability $597 \mathrm{NH}_{4}^{+}$and $\left.\mathrm{NO}_{3}^{-}\right)$are the most important parameters that contribute to the composition of soil 598 microbial communities (Fig. 7). Furthermore, Reynolds et al. (2003) have demonstrated that 599 microbe-mediated partitioning of soil resources could contribute to the coexistence of plant species 600 through associations with different microbial symbionts. Hence, soil microbes alter the availability 601 of different forms of $\mathrm{N}$, and indirectly affect plant-plant interactions by mediating soil resource 602 partitioning. 


\section{Conclusions}

604

605 The present study shows that there are soil age-driven changes in Populus-Salix interactions, from 606 positive to negative during the primary succession in the Gongga Mountain glacier retreat area. Our 607 study reveals that Populus-Salix interactions exhibit facilitation for survival under 20-year-old soil, 608 whereas under 40-year-old soil conditions, Populus-Salix interactions involve competition to avoid 609 elimination. Moreover, soil microbes and nutrients (particularly N) are major factors for the 610 transformation of Populus-Salix interactions from positive to negative. Our results support the stress 611 gradient hypothesis, which predicts that positive and negative interactions vary inversely along 612 abiotic stress gradients, with positive interaction being more common under high abiotic stress 613 when compared to more benign abiotic conditions. These findings improve our understanding of 614 plant-plant interactions and plant-soil feedbacks in subalpine forest ecosystems. However, further 615 research is still needed on energy flows and nutrient cycles in plant-soil-microbe systems, on the 616 effects of neighboring plants and microbial feedbacks, and on the dynamic models of primary 617 succession in a glacier retreat area.

Acknowledgements This work was supported by the Talent Program of the Hangzhou Normal 621 University (2016QDL020). We thank LetPub (www.letpub.com) for its linguistic assistance during 622 the preparation of this manuscript. 


\section{References}

Aneja, M.K., Sharma, S., Fleischmann, F., Stich, S., Heller, W., Bahnweg, G., Munch, J.C., Schloter, M., 2006. Microbial colonization of beech and spruce litter-influence of decomposition site and plant litter species on the diversity of microbial community. Microb. Ecol. 52, 127-135.

Arroyo, A.I., Pueyo, Y., Saiz, H., Alados, C.L., 2015. Plant-plant interactions as a mechanism structuring plant diversity in a Mediterranean semi-arid ecosystem. Ecol. Evol. 5, 5305-5317.

Bertness, M.D., Callaway, R., 1994. Positive interactions in communities. Trends Ecol. Evol. 9, 191-193.

Bever, J.D., Dickie, I.A., Facelli, E., Facelli, J.M., Klironomos, J., Moora, M., Rilling, M.C., Stock, W.D., Tibbett, M., Zobel, M., 2010. Rooting theories of plant community ecology in microbial interactions. Trends Ecol. Evol. 25, 468-478.

Bever, J.D., Westover, K.M., Antonovics, J., 1997. Incorporating the soil community into plant population dynamics: the utility of the feedback approach. J. Ecol. 85, 561-573.

Bohlen, P.J., Groffman, P.M., Driscoll, C.T., Fahey, T.J., Siccama, T.G., 2001. Plant-soil-microbial interactions in a northern hardwood forest. Ecology 82, 965-978.

Bossio, D.A., Scow, K.M., Gunapala, N., Graham, K.J., 1998. Determinants of soil microbial communities: effects of agricultural management, season, and soil type on phospholipid fatty acid profiles. Microb. Ecol. 36, 1-12.

Brookes, P.C., Landman, A., Pruden, G., Jenkinson, D.S., 1985. Chloroform fumigation and the release of soil nitrogen: a rapid direct extraction method to measure microbial biomass nitrogen in soil. Soil Biol. Biochem. 17, 837-842.

Brooker, R.W., Callaghan, T.V., 1998. The balance between positive and negative plant interactions 
and its relationship to environmental gradients: a model. Oikos 81, 196-207.

Brooker, R.W., 2006. Plant-plant interactions and environmental change. New Phytol. 171, 271-284.

Bruno, J.F., Stachowicz, J.J., Bertness, M.D., 2003. Inclusion of facilitation into ecological theory. Trends Ecol. Evol. 18, 119-125.

Callaway, R.M., 1997. Positive interactions in plant communities and the individualistic-continuum concept. Oecologia 112, 143-149.

Callaway, R.M., Walker, L.R., 1997. Competition and facilitation: a synthetic approach to interactions in plant communities. Ecology 78, 1958-1965.

Callaway, R.M., Brooker, R.W., Choler, P., Kikvidze, Z., Lortie, C.J., Michalet, R., Paolini, L., Pugnaire, F.I., Cook, B.J., Aschehoug, E.T., Armas, C., Newingham, B., 2002. Positive interactions among alpine plants increases with stress: a global experiment. Nature 417, 844-848.

Castle, S.C., Lekberg, Y., Affleck, D., Cleveland, C.C., 2016. Soil abiotic and biotic controls on plant performance during primary succession in a glacial landscape. J. Ecol. 104, 1555-1565.

Chapin, F.S., Shaver, G.R., 1985. Individualistic growth response of tundra plant species to environmental manipulations in the field. Ecology 66, 564-576.

Chapin, F.S., Walker, L.R., Fastie, C.L., Sharman, L.C., 1994. Mechanisms of primary succession following deglaciation at Glacier Bay, Alaska. Ecol. Monogr. 64, 149-175.

Chen, J., Duan, B.L., Wang, M.L., Korpelainen, H., Li, C.Y., 2014. Intra- and inter-sexual competition of Populus cathayana under different watering regimes. Funct. Ecol. 28, 124-136.

Chen, J., Dong, T.F., Duan, B.L., Korpelainen, H., Niinemets, Ü., Li, C.Y., 2015. Sexual competition and $\mathrm{N}$ supply interactively affect the dimorphism and competiveness of opposite 
sexes in Populus cathayana. Plant Cell Environ. 38, 1285-1298.

668 Choler, P., Michalet, R., Callaway, R.M., 2001. Facilitation and competition on gradients in alpine 669

Connell, J.H., 1983. On the prevalence and relative importance of interspecific competition: evidence from field experiments. Amer. Nat. 122, 661-696. Funct. Ecol. 27, 833-840.

Dohn, J., Dembélé, F., Karembé, M., Moustakas, A., Amévor, K. A., Hanan, N. P., 2013. Tree effects on grass growth in savannas: competition, facilitation and the stress-gradient hypothesis. J. Ecol. 101, 202-209.

Dong, T.F., Li, J.Y., Zhang, Y.X., Korpelainen, H., Niinemets, Ü., Li, C.Y., 2015. Partial shading of lateral branches affects growth, and foliage nitrogen- and water-use efficiencies in the conifer Cunninghamia lanceolata growing in a warm monsoon climate. Tree physiol. 35, 632-643.

Duan, B.L., Zhang, Y.B., Xu, G., Chen, J., Paquette, A., Peng, S., 2015. Long-term responses of plant growth, soil microbial communities and soil enzyme activities to elevated $\mathrm{CO}_{2}$ and neighbouring plants. Agri. For. Meteorol. 213, 91-101.

Farquhar, G.D., Ehleringer, J.R., Hubick, K.T., 1989. Carbon isotope discrimination and photosynthesis. Annu. Rev. Plant Biol. 40, 503-537.

Fawcett, J.K., 1954. The semi-micro Kjeldahl method for the determination of nitrogen. J. Med. Lab. Technol. 12, 1-22.

Federle, T.W., 1986. Microbial distribution in the soil-new techniques. In: Megusar, F., Gantar, M. (Eds.), Perspectives in Microbial Ecology. Slovene Society for Microbiology, Ljubljana, 
690 Fowler, N., 1986. The role of competition in plant communities in arid and semiarid regions. Annu. Rev. Ecol. Evol. S. 17, 89-110.

Frostegård, Å., Tunlidb, A., Bååth, E., 1991. Microbial biomass measured as total lipid phosphate in soils of different organic content. J. Microbiol. Meth. 14, 151-163. 
711 Guo, Q.X., Zhang, Y.X., Wang, D.L., Zhang, Y.B., Korpelainen, H., Li, C.Y., 2017. Influence of soil qualities on intra- and interspecific competition dynamics of Larix kaempferi, and L. olgensis. Environ. Exp. Bot. 135, 96-105.

He, Q., Bertness, M.D., Altieri, A.H., 2013. Global shifts towards positive species interactions with increasing environmental stress. Ecol. Lett. 16, 695-706.

He, L., Tang, Y., 2008. Soil development along primary succession sequences on moraines of Hailuogou Glacier, Gongga Mountain, Sichuan, China. Catena 72, 259-269.

Hodkinson, I.D., Coulson, S.J., Webb, N.R., 2003. Community assembly along proglacial chronosequences in the high Arctic: vegetation and soil development in north-west Svalbard. J. Ecol. 91, 651-663.

He, Q., Bertness, M.D., Altieri, A.H., 2013. Global shifts towards positive species interactions with increasing environmental stress. Ecol. Lett. 16, 695-706.

Huang, Z.Q., Wan, X.H., He, Z.M., Yu, Z.P., Wang, M.H., Hu, Z.H., Yang, Y.S., 2013. Soil microbial biomass, community composition and soil nitrogen cycling in relation to tree species in subtropical China. Soil Biol. Biochem. 62, 68-75.

Huston, M.A., DeAngelis, D.L., 1994. Competition and coexistence: the effects of resource transport and supply rates. Amer. Nat. 144, 954-977.

Jia, G.M., Cao, J., Wang, C., Wang, G., 2005. Microbial biomass and nutrients in soil at the different stages of secondary forest succession in Ziwulin, northwest China. For. Ecol. Manage. 217, $117-125$.

Jiang, Y.L., Song, M.Y., Zhang, S., Cai, Z.Q., Lei, Y.B., 2018. Unravelling community assemblages through multi-element stoichiometry in plant leaves and roots across primary successional 
stages in a glacier retreat area. Plant Soil 428, 291-305.

Jiang, Y.L., Lei, Y.B., Qin, W., Korpelainen, H., Li, C.Y., 2019. Revealing microbial processes and nutrient limitation in soil through ecoenzymatic stoichiometry and glomalin-related soil proteins in a retreating glacier forefield. Geoderma 338, 313-324.

Kandeler, E., 1996. In: Schinner, F., Ohlinger, R., Kandeler, E., Margesin, R. (Eds.), Methods in Soil Biology. Springer-Verlag, Heidelberg, New York, pp. 176-179.

Kandeler, E., Gerber, H., 1988. Short-term assay of soil urease activity using colorimetric determination of ammonium. Biol. Fert. Soils 6, 68-72.

Kardol, P., Cornips, N.J., van Kempen, M.M., Bakx-Schotman, J.M., van der Putten, W.H., 2007. Microbe-mediated plant-soil feedback causes historical contingency effects in plant community assembly. Ecol. Monogr. 77, 147-162.

Kardol, P., Wardle, D.A., 2010. How understanding aboveground-belowground linkages can assist restoration ecology. Trends Ecol. Evol. 25, 670-679.

Kaye, J.P., Hart, S.C., 1997. Competition for nitrogen between plants and soil microorganisms. Trends Ecol. Evol. 12, 139-143.

Kéfi, S., Holmgren, M., Scheffer, M., 2016. When can positive interactions cause alternative stable states in ecosystems? Funct. Ecol. 30, 88-97.

Kikvidze, Z., Khetsuriani, L., Kikodze, D., Callaway, R.M., 2006. Seasonal shifts in competition and facilitation in subalpine plant communities of the central Caucasus. J. Veg. Sci. 17, 77-82.

Kulmatiski, A., Beard, K., Stevens, J., Cobbold, S., 2008. Plant-soil feedbacks: a meta-analytical review. Ecol. Lett. 11, 980-992.

Lei, Y.B., Zhou, J., Xiao, H.F., Duan, B.L., Wu, Y.H., Korpelainen, H., Li, C.Y., 2015. Soil 
nematode assemblages as bioindicators of primary succession along a 120-year-old chronosequence on the Hailuogou Glacier forefield, SW China. Soil Biol. Biochem. 88, $362-371$.

Lin, Y., Berger, U., Grimm, V., Ji, Q.R., 2012. Differences between symmetric and asymmetric facilitation matter: exploring the interplay between modes of positive and negative plant interactions. J. Ecol. 100, 1482-1491.

Liu, Q., Liu, S.Y., Zhang, Y., Wang, X., Zhang, Y.S., Guo, W.Q., Xu, J.L., 2010. Recent shrinkage and hydrological response of Hailuogou glacier, a monsoon temperate glacier on the east slope of Mount Gongga, China. J. Glaciol. 56, 215-224.

Mairura, F.S., Mugendi, D.N., Mwanje, J.I., Ramisch, J.J., Mbugua, P.K., Chianu, J.N., 2007. Integrating scientific and farmers' evaluation of soil quality indicators in Central Kenya. Geoderma 139, 134-143.

Maestre, F.T., Valladares, F., Reynolds, J.F., 2005. Is the change of plant-plant interactions with abiotic stress predictable? A meta-analysis of field results in arid environments. J. Ecol. 93, 748-757.

Mariotte, P., Mehrabi, Z., Bezemer, T. M., De Deyn, G. B., Kulmatiski, A., Drigo, B., Veen, G.F., van der Heijden M.G.A., Kardol, P., 2018. Plant-soil feedback: bridging natural and agricultural sciences. Trends Ecol. Evol. 33, 129-142.

Michalet, R., Le Bagousse-Pinguet, Y., Maalouf, J. P., Lortie, C. J., 2014. Two alternatives to the stress-gradient hypothesis at the edge of life: the collapse of facilitation and the switch from facilitation to competition. J. Veg. Sci. 25, 609-613.

Murata, T., Akazawa, T., Fukuchi, S., 1968. Enzymic mechanism of starch breakdown in 
germinating rice seeds I. An analytical study. Plant Physiol. 43, 1899-1905.

Nadelhoffer, K.J., Giblin, A.E., Shaver, G.R., Laundre, J.A., 1991. Effects of temperature and substrate quality on element mineralization in six arctic soils. Ecology 72, 242-253.

Nelson, D.W., Sommers, L.E., 1982. Total carbon, organic carbon, and organic matter. Methods of soil analysis. Part 2: Chemical and microbiological properties. The American Society of Agronomy, Madison, pp. 539-579.

Olsen, S.L., Töpper, J.P., Skarpaas, O., Vandvik, V., Klanderud, K., 2004. From facilitation to competition: temperature-driven shift in dominant plant interactions affects population dynamics in seminatural grasslands. Global Change Biol. 22, 1915-1926.

Parkinson, J.A., Allen, S.E., 1975. A wet oxidation procedure suitable for the determination of nitrogen and mineral nutrients in biological material. Commun. Soil Sci. Plan. 6, 1-11.

Qi, M., Sun, T., Xue, S.F., Yang, W., Shao, D.D., Martínez-López, J., 2018. Competitive ability, stress tolerance and plant interactions along stress gradients. Ecology 99, 848-857.

Reynolds, H.L., Packer, A., Bever, J.D., Clay, K., 2003. Grassroots ecology: plant-microbe-soil interactions as drivers of plant community structure and dynamics. Ecology 84, 2281-2291.

Robinson, C.H., Wookey, P.A., Parsons, A.N., Potter, J.A., Callaghan, T.V., Lee, J.A., Press, M.C., Welker, J.M., 1995. Responses of plant litter decomposition and nitrogen mineralization to simulated environmental change in a high arctic polar semi-desert and a subarctic dwarf shrub heath. Oikos 74, 503-512.

Schindlbacher, A., Rodler, A., Kuffner, M., Kitzler, B., Sessitsch, A., Zechmeister-Boltenstern, S., 2011. Experimental warming effects on the microbial community of a temperate mountain forest soil. Soil Biol. Biochem. 43, 1417-1425. 
Smithwick, E.A., Turner, M.G., Metzger, K.L., Balser, T.C., 2005. Variation in $\mathrm{NH}_{4}^{+}$mineralization and microbial communities with stand age in lodgepole pine (Pinus contorta) forests, Yellowstone National Park (USA). Soil Biol. Biochem. 37, 1546-1559.

Song, M.Y., Yu, L., Jiang, Y.L., Lei, Y.B., Korpelainen, H., Niinemets, Ü., Li, C.Y., 2017. Nitrogen-controlled intra- and interspecific competition between Populus purdomii and Salix rehderiana drive primary succession in the Gongga Mountain glacier retreat area. Tree Physiol. $37,799-814$.

Stephan, A., Meyer, A.H., Schmid, B., 2000. Plant diversity affects culturable soil bacteria in experimental grassland communities. J. Ecol. 88, 988-998.

Swallow, M., Quideau, S.A., Mackenzie, M.D., Kishchuk, B.E., 2009. Microbial community structure and function: the effect of silvicultural burning and topographic variability in northern alberta. Soil Biol. Biochem. 41, 770-777.

Teste, F.P., Kardol, P., Turner, B.L., Wardle, D.A., Zemunik, D., Renton, M., Laliberté, E., 2006. Plant-soil feedback and the maintenance of diversity in Mediterranean-climate shrublands. Science 355, 173-176.

Travis, J.M.J., Brooker, R.W., Clark, E.J., Dytham, C., 2006. The distribution of positive and negative species interactions across environmental gradients on a dual-lattice model. J. Theor. Biol. 241, 896-902.

Ushio, M., Aiba, S.I., Takeuchi, Y., Iida, Y., Matsuoka, S., Repin, R., Kitayama, K., 2016. Plant-soil feedbacks and the dominance of conifers in a tropical montane forest in Borneo. Ecol. Monogr. 87, 105-129.

Van der Putten, W.H., Peters, B.A.M., 1997. How soil-borne pathogens may affect plant competition. 
Van der Heijden, M.G.A., Bardgett, R.D., Van Straalen, N.M., 2008. The unseen majority: soil microbes as drivers of plant diversity and productivity in terrestrial ecosystems. Ecol. Lett. 11, 296-310.

Van der Heijden, M.G.A., Bakker, R., Verwaal, J., Scheublin, T.R., Rutten, M., Van Logtestijn, R., Staehelin, C., 2006. Symbiotic bacteria as a determinant of plant community structure and plant productivity in dune grassland. FEMS Microbiol. Ecol. 56, 178-187.

Vance, E.D., Brookes, P.C., Jenkinson, D.S., 1987. An extraction method for measuring soil microbial biomass C. Soil Biol. Biochem. 19, 703-707.

Waldrop, M.P., Zak, D.R., Sinsabaugh, R.L., 2004. Microbial community response to nitrogen deposition in northern forest ecosystems. Soil Biol. Biochem. 36, 1443-1451.

Vepsäläinen, M., Kukkonen, S., Vestberg, M., Sirviö, H., Niemi, R.M., 2001. Application of soil enzyme activity test kit in a field experiment. Soil Biol. Biochem. 33, 1665-1672.

Walker, L.R., Wardle, D.A., Bardgett, R.D., Clarkson, B.D., 2010. The use of chronosequences in studies of ecological succession and soil development. J. Ecol. 98, 725-736.

Wang, J.P., Wu, Y.H., Zhou, J., Bing, H.J., Sun, H.Y., 2016. Carbon demand drives microbial mineralization of organic phosphorus during the early stage of soil development. Biol. Fert. Soils 52, 825-839.

Wardle, D.A., Bardgett, R.D., Klironomos, J.N., Setälä, H., Van Der Putten, W.H., Wall, D.H., 2004. Ecological linkages between aboveground and belowground biota. Science 304, 1629-1633.

Westover, K.M., Kennedy, A.C., Kelley, S.E., 1997. Patterns of rhizosphere microbial community structure associated with co-occurring plant species. J. Ecol. 85, 863-873. 
Xu, G., Chen, J., Berninger, F., Pumpanen, J., Bai, J.W., Yu, L., Duan, B.L., 2015. Labile, recalcitrant, microbial carbon and nitrogen and the microbial community composition at two Abies faxoniana forest elevations under elevated temperatures. Soil Biol. Biochem. 91, 1-13.

Yang, Y., Wang, G.X., Shen, H.H., Yang, Y., Cui, H.J., Liu, Q., 2014. Dynamics of carbon and nitrogen accumulation and $\mathrm{C}: \mathrm{N}$ stoichiometry in a deciduous broadleaf forest of deglaciated terrain in the eastern Tibetan Plateau. For. Ecol. Manage. 312, 10-18.

Yemm, E.W., Willis, A.J., 1954. The estimation of carbohydrates in plant extracts byanthrone. Biochemistry 57, 508-514.

Zechmeister-Boltenstern, S., Keiblinger, K.M., Mooshammer, M., Peñuelas, J., Richter, A., Sardans, J., Wanek, W., 2015. The application of ecological stoichiometry to plant-microbial-soil organic matter transformations. Ecol. Monogr. 85, 133-155.

Zelles, L., 1997. Phospholipid fatty acid profiles in selected members of soil microbial communities. Chemosphere 35, 275-294.

Zhao, H.M., Huang, G., Ma, J., Li, Y., Tang, L.S., 2014. Decomposition of aboveground and root litter for three desert herbs: mass loss and dynamics of mineral nutrients. Biol. Fert. Soils 50, $745-753$.

Zhao, H.X., Li, Y., Duan, B.L., Korpelainen, H., Li, C.Y., 2009. Sex-related adaptive responses of Populus cathayana to photoperiod transitions. Plant Cell Environ. 32, 1401-1411.

Zhou, J., Wu, Y.H., Prietzel, J., Bing, H.J., Yu, D., Sun, S.Q., Luo, J., Sun, H.Y., 2013. Changes of soil phosphorus speciation along a 120-year soil chronosequence in the Hailuogou Glacier retreat area (Gongga Mountain, SW China). Geoderma 195, 251-259. 
Table 1. Changes of soil chemical properties, extracellular enzyme activities, soil microbial biomass $\mathrm{C}$, and 865 microbial biomass $\mathrm{N}$ under different soil age and plant-plant interaction conditions.

\begin{tabular}{|c|c|c|c|c|c|c|}
\hline \multirow{2}{*}{ Soil properties } & \multicolumn{3}{|c|}{ 20-year-old soil } & \multicolumn{3}{|c|}{ 40-year-old soil } \\
\hline & PP & SS & PS & $\mathrm{PP}$ & SS & PS \\
\hline $\mathrm{SOC}\left(\mathrm{g} \cdot \mathrm{kg}^{-1}\right)$ & $6.52 \pm 0.24 \mathrm{~b}$ & $7.57 \pm 0.31 b$ & $6.98 \pm 0.11 b$ & $16.75 \pm 0.41 \mathrm{a}$ & $17.47 \pm 0.89 \mathrm{a}$ & $16.38 \pm 0.19 \mathrm{a}$ \\
\hline $\mathrm{TN}\left(\mathrm{g} \cdot \mathrm{kg}^{-1}\right)$ & $0.49 \pm 0.03 \mathrm{~b}$ & $0.56 \pm 0.02 b$ & $0.56 \pm 0.04 \mathrm{~b}$ & $0.74 \pm 0.03 \mathrm{a}$ & $0.81 \pm 0.06 \mathrm{a}$ & $0.73 \pm 0.02 \mathrm{a}$ \\
\hline $\mathrm{TP}\left(\mathrm{g} \cdot \mathrm{kg}^{-1}\right)$ & $1.30 \pm 0.05 \mathrm{a}$ & $1.23 \pm 0.02 \mathrm{a}$ & $1.26 \pm 0.05 \mathrm{a}$ & $1.18 \pm 0.10 \mathrm{a}$ & $1.54 \pm 0.19 \mathrm{a}$ & $1.17 \pm 0.07 \mathrm{a}$ \\
\hline $\mathrm{TK}\left(\mathrm{g} \cdot \mathrm{kg}^{-1}\right)$ & $48.77 \pm 0.32 \mathrm{ab}$ & $48.77 \pm 0.17 \mathrm{ab}$ & $50.02 \pm 0.26 \mathrm{a}$ & $48.12 \pm 0.80 \mathrm{abc}$ & $45.97 \pm 0.23 \mathrm{c}$ & $46.97 \pm 0.78 \mathrm{bc}$ \\
\hline $\mathrm{AN}\left(\mathrm{mg} \cdot \mathrm{kg}^{-1}\right)$ & $93.30 \pm 2.77 \mathrm{c}$ & $95.15 \pm 3.00 \mathrm{c}$ & $102.68 \pm 5.58 \mathrm{c}$ & $143.98 \pm 6.16 \mathrm{ab}$ & $154.21 \pm 3.73 \mathrm{a}$ & $129.77 \pm 3.91 \mathrm{~b}$ \\
\hline $\mathrm{AP}\left(\mathrm{mg} \cdot \mathrm{kg}^{-1}\right)$ & $60.79 \pm 0.80 \mathrm{ab}$ & $54.76 \pm 1.27 \mathrm{bc}$ & $61.17 \pm 1.83 \mathrm{ab}$ & $53.46 \pm 1.49 \mathrm{c}$ & $62.54 \pm 0.59 \mathrm{a}$ & $60.25 \pm 2.48 \mathrm{ab}$ \\
\hline $\mathrm{AK}\left(\mathrm{mg} \cdot \mathrm{kg}^{-1}\right)$ & $187.04 \pm 1.85 \mathrm{ab}$ & $183.47 \pm 3.74 \mathrm{~b}$ & $207.64 \pm 5.89 \mathrm{a}$ & $181.17 \pm 4.98 \mathrm{~b}$ & $165.38 \pm 1.94 \mathrm{~b}$ & $183.63 \pm 7.06 \mathrm{~b}$ \\
\hline $\mathrm{NH}_{4}{ }^{+}-\mathrm{N}\left(\mathrm{mg} \cdot \mathrm{kg}^{-1}\right)$ & $15.47 \pm 0.93 \mathrm{~b}$ & $15.76 \pm 0.42 b$ & $15.63 \pm 1.37 \mathrm{~b}$ & $21.04 \pm 1.07 \mathrm{a}$ & $22.51 \pm 1.39 \mathrm{a}$ & $19.63 \pm 0.79 \mathrm{a}$ \\
\hline $\mathrm{NO}_{3}{ }^{-}-\mathrm{N}\left(\mathrm{mg} \cdot \mathrm{kg}^{-1}\right)$ & $33.68 \pm 2.22 b$ & $31.44 \pm 1.35 \mathrm{~b}$ & $33.53 \pm 2.94 \mathrm{~b}$ & $42.38 \pm 1.47 \mathrm{a}$ & $44.16 \pm 1.85 \mathrm{a}$ & $40.58 \pm 3.19 \mathrm{a}$ \\
\hline $\operatorname{MBC}\left(\mathrm{mg} \cdot \mathrm{kg}^{-1}\right)$ & $256.26 \pm 4.67 \mathrm{c}$ & $274.11 \pm 3.25 \mathrm{c}$ & $246.69 \pm 5.44 \mathrm{~cd}$ & $345.40 \pm 5.98 \mathrm{ab}$ & $347.05 \pm 4.96 \mathrm{a}$ & $323.76 \pm 3.51 \mathrm{~b}$ \\
\hline $\operatorname{MBN}\left(\mathrm{mg} \cdot \mathrm{kg}^{-1}\right)$ & $9.24 \pm 0.25 \mathrm{c}$ & $9.51 \pm 0.14 \mathrm{c}$ & $8.90 \pm 0.19 \mathrm{c}$ & $15.49 \pm 0.38 \mathrm{ab}$ & $16.55 \pm 0.35 \mathrm{a}$ & $14.53 \pm 0.13 b$ \\
\hline MBC:MBN ratio & $27.76 \pm 0.96 \mathrm{a}$ & $28.83 \pm 0.49 \mathrm{a}$ & $27.72 \pm 0.14 \mathrm{a}$ & $22.33 \pm 0.73 b$ & $20.98 \pm 0.22 \mathrm{~b}$ & $22.29 \pm 0.34 \mathrm{~b}$ \\
\hline $\begin{array}{l}\text { Urease activity } \\
\left(\mu \mathrm{g} \mathrm{NH} 4-\mathrm{N} \cdot \mathrm{g}^{-1} \cdot \mathrm{soil} \cdot \mathrm{h}^{-1}\right)\end{array}$ & $15.19 \pm 0.39 \mathrm{~b}$ & $13.81 \pm 0.28 b$ & $13.17 \pm 0.47 \mathrm{~b}$ & $19.23 \pm 0.47 \mathrm{a}$ & $19.94 \pm 0.41 \mathrm{a}$ & $19.52 \pm 0.81 \mathrm{a}$ \\
\hline 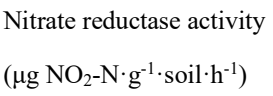 & $5.39 \pm 0.25 b c$ & $4.06 \pm 0.51 \mathrm{~b}$ & $4.83 \pm 0.33 b c$ & $6.73 \pm 0.57 \mathrm{ab}$ & $7.68 \pm 0.17 \mathrm{a}$ & $6.47 \pm 0.57 \mathrm{ab}$ \\
\hline $\begin{array}{l}\text { Saccharase activity } \\
\left(\mu \mathrm{g} \text { glucose } \cdot \mathrm{g}^{-1} \cdot \mathrm{soil} \cdot \mathrm{h}^{-1}\right)\end{array}$ & $132.79 \pm 3.21 \mathrm{~b}$ & $139.46 \pm 3.38 \mathrm{~b}$ & $126.98 \pm 1.86 b$ & $184.81 \pm 2.92 \mathrm{a}$ & $180.71 \pm 4.09 \mathrm{a}$ & $175.89 \pm 4.06 \mathrm{a}$ \\
\hline $\mathrm{pH}$ value & $6.65 \pm 0.05 \mathrm{a}$ & $6.80 \pm 0.10 \mathrm{a}$ & $6.68 \pm 0.05 \mathrm{a}$ & $6.03 \pm 0.15 b$ & $6.52 \pm 0.19 \mathrm{ab}$ & $6.00 \pm 0.11 b$ \\
\hline
\end{tabular}

866 SOC, soil organic carbon; TN, soil total nitrogen; TP, soil total phosphorus; TK, soil total potassium; AN, soil 867 alkali-hydrolyzable nitrogen; AP, soil available phosphorus; AK, soil available potassium; $\mathrm{NH}_{4}{ }^{+}-\mathrm{N}$, soil 868 ammonium nitrogen; $\mathrm{NO}_{3}{ }^{-}-\mathrm{N}$, soil nitrate nitrogen; $\mathrm{MBC}$, soil microbial biomass $\mathrm{C}$; MBN, soil microbial biomass 869 N. PP, soil sample from $P$. purdomii and $P$. purdomii intraspecific interaction; SS, soil sample from $S$. rehderiana 870 and $S$. rehderiana intraspecific interaction; PS, soil sample from $P$. purdomii and S. rehderiana interspecific 871 interaction. Values followed by same letters in the same row are not significantly different at the $P<0.05$ level 872 according to Tukey's test. Values are expressed as means $\pm \mathrm{SE}(n=4)$. 
873 Table 2. Changes of soil microbial PLFA parameters $\left(\mathrm{nmol} \mathrm{g}^{-1}\right.$ soil) under difference soil age and plant-plant 874 interactions conditions.

\begin{tabular}{|c|c|c|c|c|c|c|}
\hline \multirow{2}{*}{ PLFA markers } & \multicolumn{3}{|c|}{ 20-year-old soil } & \multicolumn{3}{|c|}{ 40-year-old soil } \\
\hline & PP & SS & PS & PP & SS & PS \\
\hline \multicolumn{7}{|l|}{ Gram-positive } \\
\hline $\mathrm{i} 14: 0$ & $0.036 \pm 0.003 \mathrm{a}$ & $0.034 \pm 0.003 \mathrm{a}$ & $0.022 \pm 0.005 \mathrm{a}$ & $0.036 \pm 0.008 \mathrm{a}$ & $0.049 \pm 0.007 \mathrm{a}$ & $0.036 \pm 0.004 \mathrm{a}$ \\
\hline $\mathrm{i} 15: 0$ & $0.497 \pm 0.039 \mathrm{a}$ & $0.503 \pm 0.033 \mathrm{a}$ & $0.533 \pm 0.035 \mathrm{a}$ & $0.534 \pm 0.121 \mathrm{a}$ & $0.627 \pm 0.056 \mathrm{a}$ & $0.405 \pm 0.010 \mathrm{a}$ \\
\hline $\mathrm{i} 15: 1 \mathrm{G}$ & $0.083 \pm 0.009 \mathrm{a}$ & $0.082 \pm 0.007 \mathrm{ab}$ & $0.028 \pm 0.016 \mathrm{~b}$ & $0.090 \pm 0.015 \mathrm{a}$ & $0.093 \pm 0.013 \mathrm{a}$ & $0.071 \pm 0.005 \mathrm{ab}$ \\
\hline i16:0 & $0.147 \pm 0.004 \mathrm{~b}$ & $0.171 \pm 0.006 \mathrm{ab}$ & $0.164 \pm 0.003 \mathrm{~b}$ & $0.204 \pm 0.012 \mathrm{a}$ & $0.205 \pm 0.007 \mathrm{a}$ & $0.151 \pm 0.007 \mathrm{~b}$ \\
\hline i17:0 & $0.156 \pm 0.006 \mathrm{ab}$ & $0.143 \pm 0.010 \mathrm{ab}$ & $0.137 \pm 0.008 \mathrm{ab}$ & $0.174 \pm 0.015 \mathrm{ab}$ & $0.205 \pm 0.029 \mathrm{a}$ & $0.115 \pm 0.009 \mathrm{~b}$ \\
\hline a15:0 & $0.329 \pm 0.024 \mathrm{a}$ & $0.337 \pm 0.015 \mathrm{a}$ & $0.361 \pm 0.038 \mathrm{a}$ & $0.406 \pm 0.077 \mathrm{a}$ & $0.466 \pm 0.033 \mathrm{a}$ & $0.303 \pm 0.013 \mathrm{a}$ \\
\hline a17:0 & $0.145 \pm 0.003 \mathrm{ab}$ & $0.167 \pm 0.006 \mathrm{ab}$ & $0.093 \pm 0.017 \mathrm{~b}$ & $0.190 \pm 0.013 \mathrm{ab}$ & $0.206 \pm 0.023 \mathrm{a}$ & $0.126 \pm 0.005 \mathrm{ab}$ \\
\hline$\Sigma$ Gram-positive & $1.392 \pm 0.076 \mathrm{ab}$ & $1.437 \pm 0.054 \mathrm{ab}$ & $1.339 \pm 0.008 \mathrm{ab}$ & $1.634 \pm 0.244 \mathrm{ab}$ & $1.851 \pm 0.169 \mathrm{a}$ & $1.207 \pm 0.033 \mathrm{~b}$ \\
\hline \multicolumn{7}{|l|}{ Gram-negative } \\
\hline $17: 1 \omega 8 \mathrm{c}$ & $0.060 \pm 0.003 \mathrm{a}$ & $0.085 \pm 0.011 \mathrm{a}$ & nd & $0.063 \pm 0.005 \mathrm{a}$ & $0.072 \pm 0.018 \mathrm{a}$ & $0.048 \pm 0.004 \mathrm{a}$ \\
\hline $18: 1 \omega 5 \mathrm{c}$ & $0.126 \pm 0.011 \mathrm{a}$ & nd & nd & $0.164 \pm 0.022 \mathrm{a}$ & $0.139 \pm 0.008 \mathrm{a}$ & $0.126 \pm 0.012 \mathrm{a}$ \\
\hline cy17:0 & $0.333 \pm 0.005 \mathrm{bc}$ & $0.400 \pm 0.005 \mathrm{ab}$ & $0.360 \pm 0.016 \mathrm{bc}$ & $0.377 \pm 0.017 \mathrm{abc}$ & $0.468 \pm 0.038 \mathrm{a}$ & $0.285 \pm 0.017 \mathrm{c}$ \\
\hline cy $19: 0 \omega 8 \mathrm{c}$ & $0.362 \pm 0.004 \mathrm{a}$ & $0.363 \pm 0.018 \mathrm{a}$ & $0.369 \pm 0.009 \mathrm{a}$ & $0.359 \pm 0.032 \mathrm{a}$ & $0.439 \pm 0.016 \mathrm{a}$ & $0.185 \pm 0.018 \mathrm{~b}$ \\
\hline $16: 12 \mathrm{OH}$ & nd & $0.041 \pm 0.005 \mathrm{~b}$ & nd & $0.028 \pm 0.005 \mathrm{bc}$ & $0.063 \pm 0.007 \mathrm{a}$ & $0.015 \pm 0.001 \mathrm{~cd}$ \\
\hline$\Sigma$ Gram-negative & $0.882 \pm 0.018 \mathrm{bc}$ & $0.889 \pm 0.054 \mathrm{bc}$ & $0.729 \pm 0.036 \mathrm{c}$ & $0.991 \pm 0.145 \mathrm{ab}$ & $1.181 \pm 0.151 \mathrm{a}$ & $0.659 \pm 0.050 \mathrm{c}$ \\
\hline \multicolumn{7}{|l|}{ AM fungi } \\
\hline $16: 1 \omega 5 \mathrm{c}$ & $0.245 \pm 0.003 \mathrm{c}$ & $0.264 \pm 0.003 \mathrm{bc}$ & $0.341 \pm 0.043 \mathrm{abc}$ & $0.364 \pm 0.034 \mathrm{ab}$ & $0.400 \pm 0.024 \mathrm{a}$ & $0.233 \pm 0.008 \mathrm{c}$ \\
\hline $16: 1 \omega 11 \mathrm{c}$ & $0.115 \pm 0.005 \mathrm{~b}$ & $0.125 \pm 0.005 \mathrm{ab}$ & $0.132 \pm 0.008 \mathrm{ab}$ & $0.163 \pm 0.022 \mathrm{ab}$ & $0.176 \pm 0.017 \mathrm{a}$ & $0.106 \pm 0.005 \mathrm{~b}$ \\
\hline$\Sigma \mathrm{AMF}$ & $0.360 \pm 0.003 \mathrm{c}$ & $0.389 \pm 0.005 \mathrm{bc}$ & $0.473 \pm 0.042 \mathrm{abc}$ & $0.527 \pm 0.036 \mathrm{ab}$ & $0.576 \pm 0.032 \mathrm{a}$ & $0.340 \pm 0.012 \mathrm{c}$ \\
\hline \multicolumn{7}{|l|}{ Fungi } \\
\hline $18: 1 \omega 9 \mathrm{c}$ & $0.565 \pm 0.024 \mathrm{bc}$ & $0.533 \pm 0.031 \mathrm{bc}$ & $0.571 \pm 0.012 \mathrm{bc}$ & $0.669 \pm 0.053 \mathrm{ab}$ & $0.768 \pm 0.065 \mathrm{a}$ & $0.390 \pm 0.021 \mathrm{c}$ \\
\hline \multicolumn{7}{|l|}{ Actinomycetes } \\
\hline 10 Me17:0 & $0.021 \pm 0.002 \mathrm{a}$ & $0.021 \pm 0.001 \mathrm{a}$ & $0.023 \pm 0.002 \mathrm{a}$ & $0.039 \pm 0.009 \mathrm{a}$ & $0.039 \pm 0.008 \mathrm{a}$ & $0.021 \pm 0.005 \mathrm{a}$ \\
\hline 10 Me18:0 & $0.136 \pm 0.004 \mathrm{~b}$ & $0.148 \pm 0.012 \mathrm{~b}$ & $0.108 \pm 0.011 \mathrm{~b}$ & $0.262 \pm 0.023 \mathrm{a}$ & $0.228 \pm 0.024 \mathrm{a}$ & $0.122 \pm 0.002 \mathrm{~b}$ \\
\hline$\Sigma$ Actinomycetes & $0.157 \pm 0.002 \mathrm{~b}$ & $0.169 \pm 0.012 \mathrm{~b}$ & $0.131 \pm 0.009 \mathrm{~b}$ & $0.301 \pm 0.029 \mathrm{a}$ & $0.267 \pm 0.032 \mathrm{a}$ & $0.144 \pm 0.005 \mathrm{~b}$ \\
\hline Total PLFAs & $3.356 \pm 0.162 \mathrm{bc}$ & $3.418 \pm 0.211 \mathrm{bc}$ & $3.244 \pm 0.122 \mathrm{bc}$ & $4.122 \pm 0.765 \mathrm{ab}$ & $4.644 \pm 0.639$ a & $2.739 \pm 0.109 \mathrm{c}$ \\
\hline Gram+/Gram- ratio & $1.576 \pm 0.098 \mathrm{a}$ & $1.617 \pm 0.094 \mathrm{a}$ & $1.842 \pm 0.127 \mathrm{a}$ & $1.632 \pm 0.180 \mathrm{a}$ & $1.563 \pm 0.051 \mathrm{a}$ & $1.839 \pm 0.155 \mathrm{a}$ \\
\hline Fungi/Bacteria ratio & $0.249 \pm 0.028 \mathrm{abc}$ & $0.229 \pm 0.012 \mathrm{bc}$ & $0.276 \pm 0.005 \mathrm{a}$ & $0.258 \pm 0.019 \mathrm{ab}$ & $0.253 \pm 0.009 a b c$ & $0.209 \pm 0.015 \mathrm{c}$ \\
\hline
\end{tabular}

875 PP, soil sample from P. purdomii and P. purdomii intraspecific interaction; SS, soil sample from S. rehderiana and

876 S. rehderiana intraspecific interaction; PS, soil sample from P. purdomii and S. rehderiana interspecific interaction.

877 Values followed by different letters in the same row are significantly different at the $P<0.05$ level according to

878 Tukey's test. nd, not detected. Values are expressed as means $\pm \operatorname{SE}(n=4)$. 
879 Table 3. Pearson correlation coefficients between soil biochemical properties and microbial lipid biomarkers.

\begin{tabular}{|c|c|c|c|c|c|c|c|c|c|}
\hline & SOC & $\mathrm{TN}$ & AN & $\mathrm{pH}$ & $\mathrm{NH}_{4}{ }^{+}-\mathrm{N}$ & $\mathrm{NO}_{3}-\mathrm{N}$ & Urease & Saccharase & $\begin{array}{l}\text { Nitrate } \\
\text { reductase }\end{array}$ \\
\hline $\mathrm{G}^{+}$ & 0.392 & $0.549^{*}$ & $0.559 *$ & 0.058 & $0.525^{*}$ & 0.415 & 0.346 & 0.407 & $0.507^{*}$ \\
\hline G- & 0.368 & $0.481^{*}$ & $0.529 *$ & 0.078 & $0.508^{*}$ & 0.402 & 0.382 & 0.399 & $0.521 *$ \\
\hline $\mathrm{G}+/ \mathrm{G}-$ ratio & -0.016 & 0.028 & -0.059 & -0.082 & -0.103 & -0.058 & -0.175 & -0.077 & -0.172 \\
\hline Bacteria & 0.391 & $0.533^{*}$ & $0.559 *$ & 0.068 & $0.529 *$ & 0.418 & 0.368 & 0.413 & $0.524 *$ \\
\hline Fungi & 0.275 & $0.473^{*}$ & $0.471^{*}$ & 0.096 & 0.438 & 0.377 & 0.232 & 0.276 & 0.433 \\
\hline $\mathrm{F} / \mathrm{B}$ ratio & -0.211 & -0.104 & -0.070 & 0.158 & -0.081 & -0.023 & -0.249 & -0.246 & -0.069 \\
\hline AM Fungi & 0.426 & $0.609 * *$ & $0.644 * *$ & -0.066 & $0.597^{*}$ & $0.528^{*}$ & 0.333 & 0.416 & $0.515^{* *}$ \\
\hline Actinomycetes & $0.650^{* *}$ & $0.690^{* *}$ & $0.746 * * *$ & -0.346 & $0.669 * *$ & $0.598 * *$ & $0.582 *$ & $0.707^{* *}$ & $0.615^{* *}$ \\
\hline Total PLFAs & 0.419 & $0.568^{*}$ & $0.601 * *$ & 0.017 & $0.562 *$ & $0.475^{*}$ & 0.378 & 0.438 & $0.541 *$ \\
\hline
\end{tabular}

$880 \mathrm{G}+$, gram-positive bacterial PLFAs; G-, gram-negative bacterial PLFAs; G+/G-, the ratio of gram-positive to 881 gram-negative bacterial PLFAs; F/B, the ratio of fungal $(18: 1 \omega 9 \mathrm{c})$ to bacterial PLFAs; AM Fungi, arbuscular 882 mycorrhizal fungi; SOC, soil organic carbon; TN, soil total nitrogen; AN, alkali-hydrolyzable nitrogen. Significant 883 correlations are shown in bold. ${ }^{*} P<0.05 ; * * P<0.01 ; * * P<0.001$. 
884 Table 4. Generalized Linear Model (GLM) results of species, soil age, plant pattern, and their interactions effects 885 on morphological traits, nutrient allocation and non-structural carbohydrates. $\mathrm{F}_{\mathrm{S}}$, species effect; $\mathrm{F}_{\mathrm{Y}}$, soil age effect; $886 \mathrm{~F}_{\mathrm{p}}$, planting pattern effect; $\mathrm{F}_{\mathrm{S} \times \mathrm{Y}}$, species $\times$ soil age effect; $\mathrm{F}_{\mathrm{S} \times \mathrm{P}}$, species $\times$ planting pattern effect; $\mathrm{F}_{\mathrm{Y} \times \mathrm{P}}$, soil age $\times$ 887 planting pattern effect; $\mathrm{F}_{\mathrm{S} \times \mathrm{Y} \times \mathrm{P}}$, species $\times$ soil age $\times$ planting pattern effect. Significant effects $(P<0.05)$ are shown 888 in a bold font.

\begin{tabular}{|c|c|c|c|c|c|c|c|}
\hline Variable & $\mathrm{P}>\mathrm{F}_{\mathrm{S}}$ & $\mathrm{P}>\mathrm{F}_{\mathrm{Y}}$ & $\mathrm{P}>\mathrm{F}_{\mathrm{P}}$ & $\mathrm{P}>\mathrm{F}_{\mathrm{S} \times \mathrm{Y}}$ & $\mathrm{P}>\mathrm{F}_{\mathrm{S} \times \mathrm{P}}$ & $\mathrm{P}>\mathrm{F}_{\mathrm{Y} \times \mathrm{P}}$ & $\mathrm{P}>\mathrm{F}_{\mathrm{S} \times \mathrm{Y} \times \mathrm{P}}$ \\
\hline Aboveground & $<0.001$ & $<0.001$ & $<0.001$ & $<0.001$ & $<0.001$ & $<0.001$ & 0.203 \\
\hline Belowground & $<0.001$ & $<0.001$ & 0.055 & 0.002 & $<0.001$ & $<0.001$ & 0.444 \\
\hline Total biomass & $<0.001$ & $<0.001$ & $<0.001$ & $<0.001$ & $<0.001$ & $<0.001$ & 0.099 \\
\hline Root:shoot radio & $<0.001$ & 0.033 & 0.025 & 0.126 & 0.868 & 0.002 & 0.868 \\
\hline Leaf $\mathrm{N}$ & 0.019 & $<0.001$ & 0.641 & 0.051 & $<0.001$ & 0.009 & $<0.001$ \\
\hline Leaf $\mathrm{P}$ & 0.322 & 0.098 & 0.953 & 0.269 & 0.150 & 0.860 & 0.861 \\
\hline Leaf C:N & 0.002 & $<0.001$ & 0.099 & 0.118 & 0.007 & 0.015 & 0.013 \\
\hline Leaf N:P & 0.472 & $<0.001$ & 0.811 & 0.023 & $<0.001$ & 0.052 & 0.012 \\
\hline Root N & 0.927 & $<0.001$ & $<0.001$ & $<0.001$ & 0.116 & $<0.001$ & 0.415 \\
\hline Root P & 0.015 & 0.015 & 0.002 & 0.166 & 0.351 & 0.352 & 0.814 \\
\hline Root C:N & 0.307 & $<0.001$ & $<0.001$ & $<0.001$ & $<0.001$ & $<0.001$ & 0.298 \\
\hline Root N:P & $<0.001$ & 0.883 & 0.401 & $<0.001$ & 0.011 & 0.089 & 0.304 \\
\hline Leaf starch & 0.333 & 0.866 & 0.004 & $<0.001$ & $<0.001$ & 0.275 & $<0.001$ \\
\hline Leaf total sugar & $<0.001$ & $<0.001$ & 0.595 & $<0.001$ & 0.149 & 0.814 & 0.072 \\
\hline Leaf sucrose & $<0.001$ & $<0.001$ & $<0.001$ & 0.912 & 0.407 & 0.231 & 0.013 \\
\hline Leaf fructose & $<0.001$ & $<0.001$ & 0.013 & 0.618 & 0.266 & 0.192 & 0.197 \\
\hline Root starch & $<0.001$ & 0.002 & 0.039 & 0.001 & $<0.001$ & 0.772 & 0.295 \\
\hline Root total sugar & $<0.001$ & $<0.001$ & 0.269 & $<0.001$ & 0.538 & $<0.001$ & 0.031 \\
\hline Root sucrose & $<0.001$ & 0.002 & 0.408 & 0.406 & 0.051 & 0.363 & 0.442 \\
\hline Root fructose & $<0.001$ & $<0.001$ & 0.134 & 0.515 & 0.006 & 0.468 & 0.093 \\
\hline
\end{tabular}


891 Figure 1. The experiment was conducted on the Gongga Mountain glacier forefield, which is located on the south-eastern fringe of the Tibetan Plateau (modified from Zhou et al. 2013). A, experimental station; S3, 20-year-old soil; S4, 40-year-old soil. S1-S7 belong to a 120-year-old soil chronosequence.

Figure 2. Growth traits of $P$. purdomii and $S$. rehderiana as affected by different soil age and plant-plant interaction conditions. Different letters above bars denote statistically significant differences between treatments at the $P<0.05$ level according to Tukey's test. Generalized Linear Model was conducted to evaluate the effects of different factors and their interactions (Table 4). Treatment codes are as follows: P/PP, P. purdomii individuals from intraspecific interaction; $\mathrm{P} / \mathrm{PS}$, P. purdomii individuals from interspecific interaction; S/SS, S. rehderiana individuals from intraspecific interaction; S/PS, S. rehderiana individuals from interspecific interaction. Values

Figure 3. Relative competition intensity of $P$. purdomii and S. rehderiana under different soil age and plant-plant

Figure 4. Leaf and root starch (a), total sugar (b), sucrose (c) and fructose (d) contents in P. purdomii and $S$. rehderiana plants under different soil age and plant-plant interaction conditions. Treatment codes are the same as those in Figure 2. Different letters above bars denote statistically significant differences between treatments at the

Figure 5. Leaf and root nitrogen (a), phosphorus (b), the ratio of carbon to nitrogen (c) and the ratio of nitrogen to phosphorus (d) contents in P. purdomii and S. rehderiana plants under different soil age and plant-plant interaction conditions. Treatment codes are the same as those in Figure 2. Different letters above bars denote statistically significant differences between treatments at the $P<0.05$ level according to Tukey's test. $P$ values for interactive effects according to Generalized Linear Model was in Table 4. Values are expressed as means \pm SE $(n=4)$. 
920 composition $\left(\delta^{13} \mathrm{C}\right)$ of $P$. purdomii and $S$. rehderiana under different soil age and plant-plant interaction conditions.

921 Treatment codes are the same as those in Figure 2. Different letters above bars denote statistically significant 922 differences between treatments at the $P<0.05$ level according to Tukey's test. Values are expressed as means \pm 923 SE $(n=4)$.

925 Figure 7. Redundancy analysis (RDA) between soil microbial PLFAs and environmental parameters. White square, soil sample from interspecific interaction of $P$. purdomii and S. rehderiana in 20-year-old soil; white star, soil sample from intraspecific interaction of P. purdomii and P. purdomii in 20-year-old soil; white inverse triangle, soil sample from intraspecific interaction of S. rehderiana and S. rehderiana in 20-year-old soil; black square, soil sample from interspecific interaction of $P$. purdomii and S. rehderiana in 40-year-old soil; black star, soil sample from intraspecific interaction of $P$. purdomii and P. purdomii in 40-year-old soil; black inverse triangle, soil sample from intraspecific interaction of $S$. rehderiana and $S$. rehderiana in 40-year-old soil; G+, gram-positive bacteria PLFAs; G-, gram-negative bacteria PLFAs; G+/G-, the ratio of gram-positive bacteria to gram-negative bacteria PLFAs; F/B, the ratio of fungi (18:1 $\omega 9 \mathrm{c})$ to bacteria PLFAs; AM Fungi, arbuscular mycorrhizal fungi; MBC, soil microbial biomass C; MBN, soil microbial biomass N; SOC, soil organic carbon; TN, soil total nitrogen; TP, soil total phosphorus; AN, soil alkali-hydrolyzable nitrogen; AP, soil available phosphorus; $\mathrm{NH}_{4}{ }^{+}-\mathrm{N}$, soil ammonium nitrogen; $\mathrm{NO}_{3}{ }^{-}-\mathrm{N}$, soil nitrate nitrogen.

Figure 8. Transmission electron microscopy observations of mesophyll cells in P. purdomii and S. rehderiana under different soil age and planting pattern conditions. (a) P. purdomii from interspecific interaction in 20-year-old soil; (b) S. rehderiana from interspecific interaction in 20-year-old soil; (c) P. purdomii from intraspecific interaction in 20-year-old soil; (d) S. rehderiana from intraspecific interaction in 20-year-old soil; (e) P. purdomii from interspecific interaction in 40 -year-old soil; (f) S. rehderiana from interspecific interaction in 40-year-old soil age; (g) P. purdomii from intraspecific interaction in 40-year-old soil; (h) S. rehderiana from intraspecific interaction in 40-year-old soil. C, chloroplast; S, starch granule; P, plastoglobulus; G, granum; CW, cell wall; V, vacuole; $\mathrm{M}$, mitochondrion; N, nucleus. The bars correspond to $1 \mu \mathrm{m}$ in all panels. 
Figure 1.

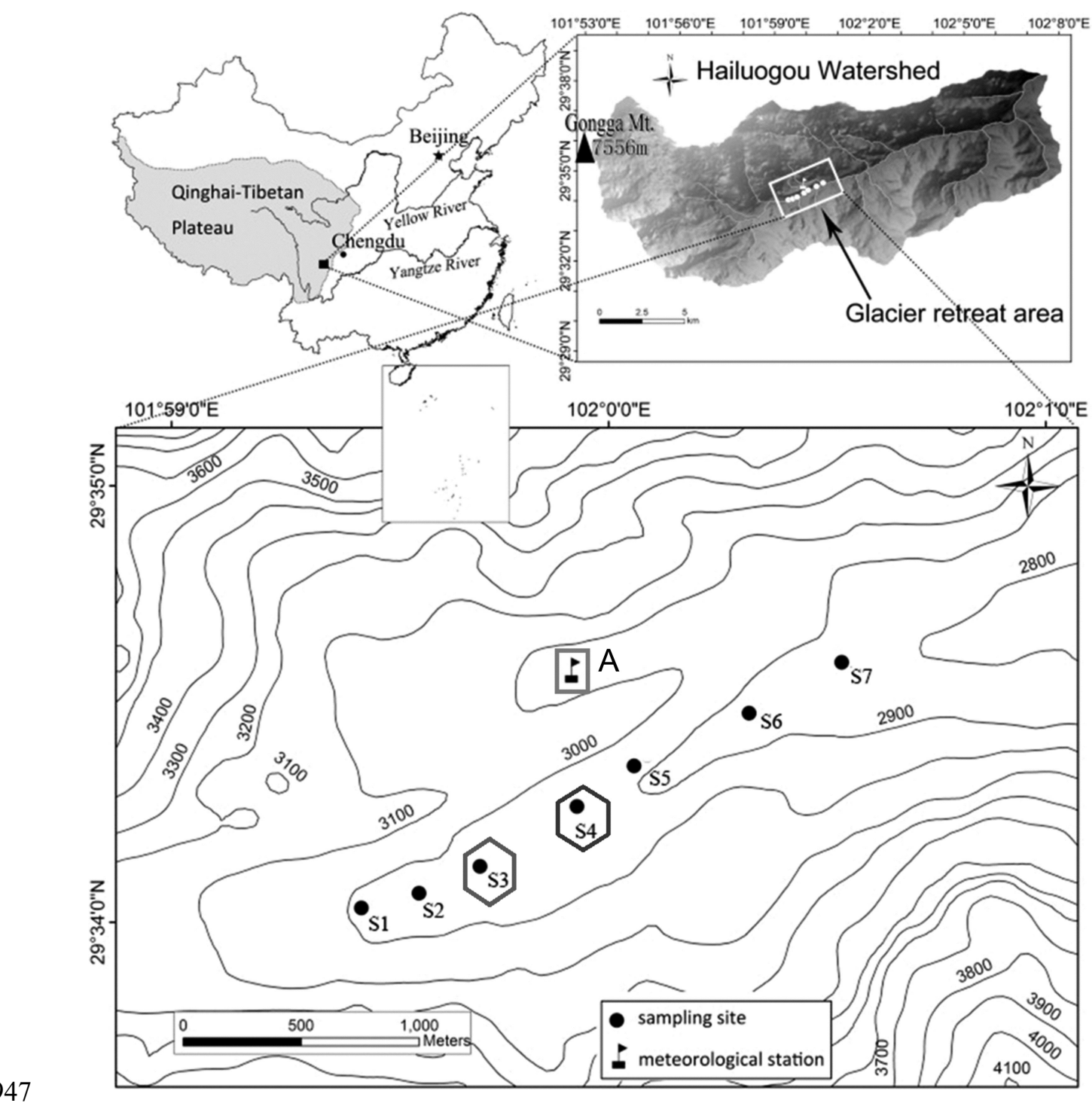


Figure 2.
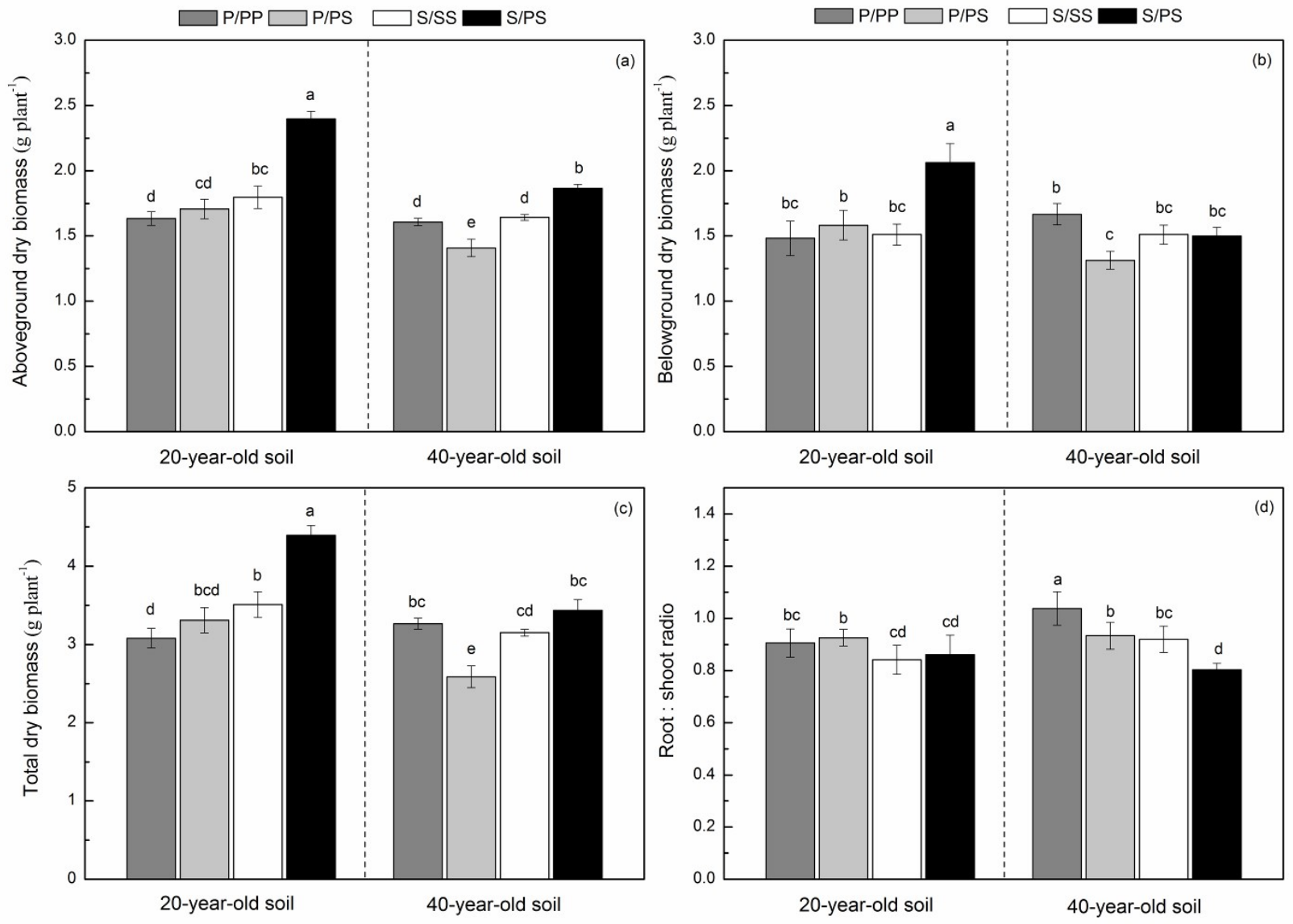
$951 \quad$ Figure 3.

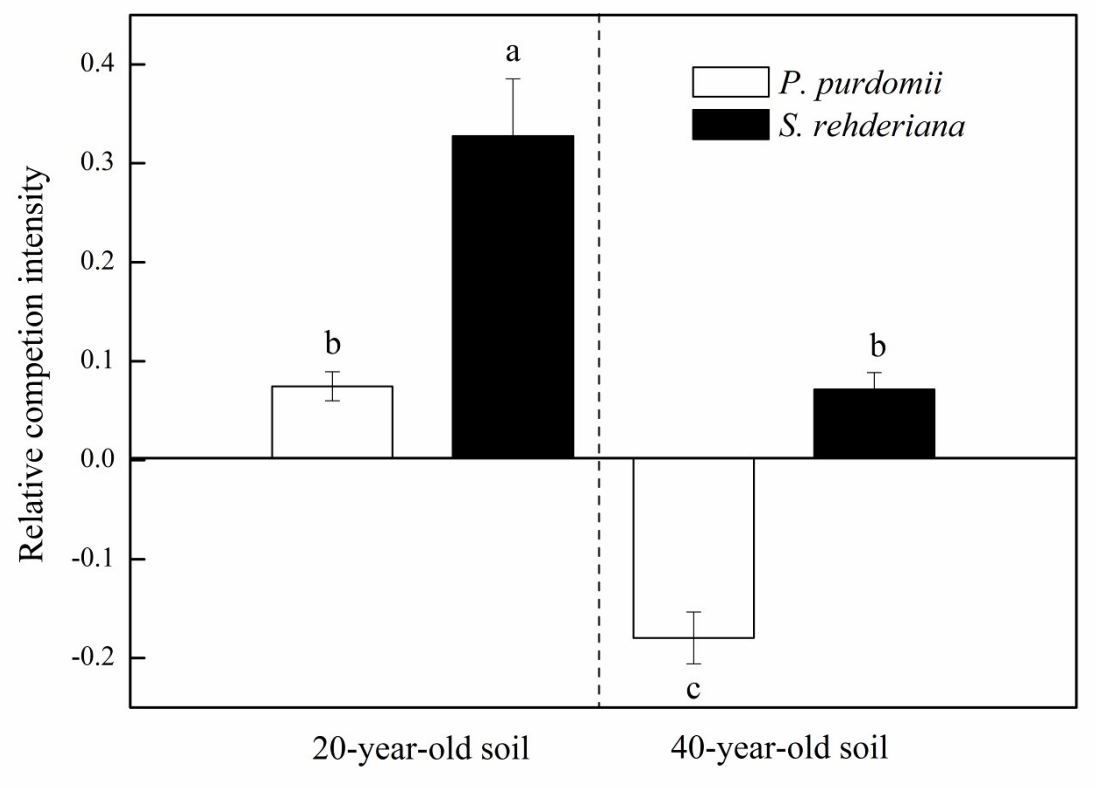

952

953 
Figure 4.
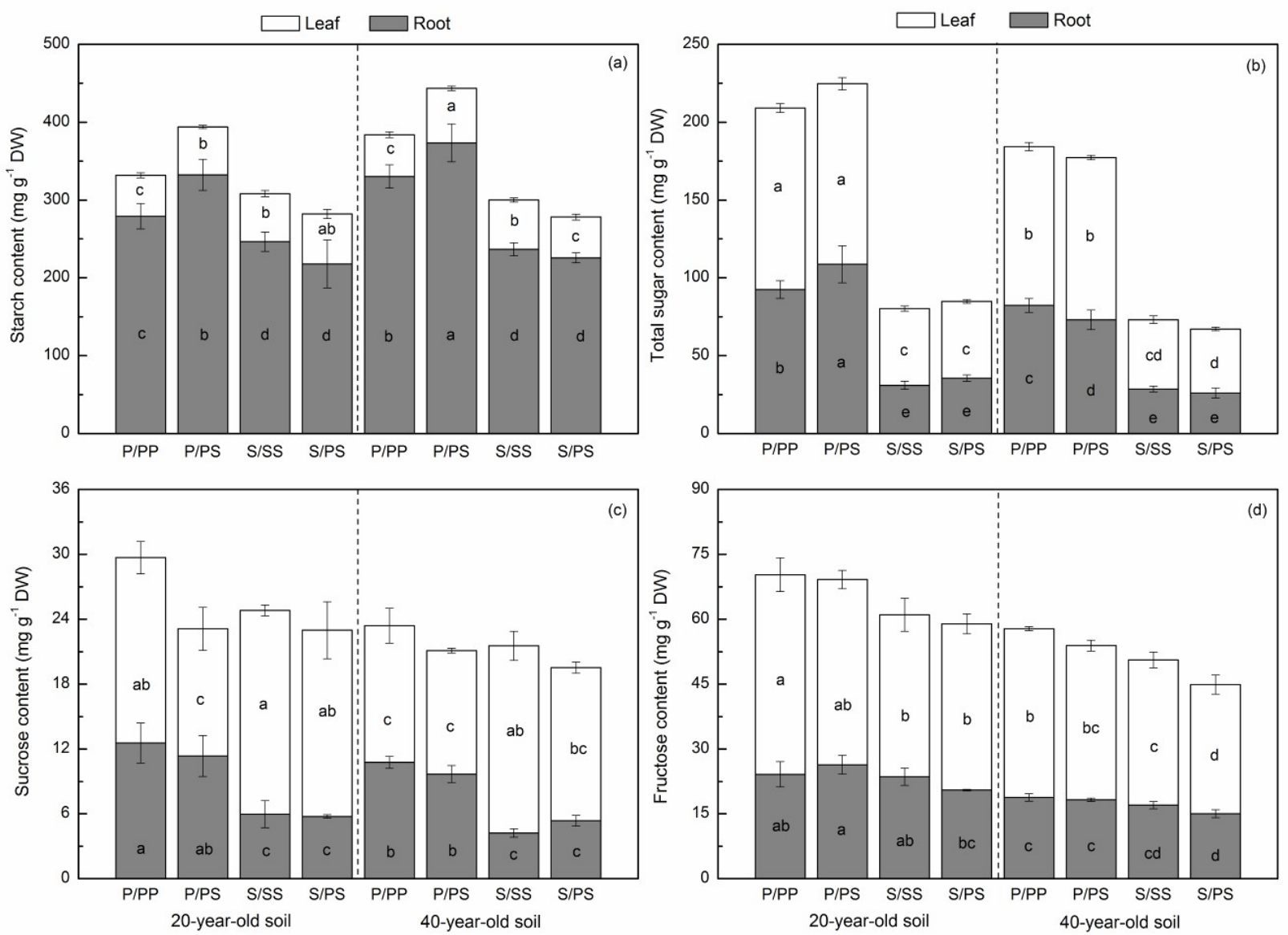

956 
Figure 5.
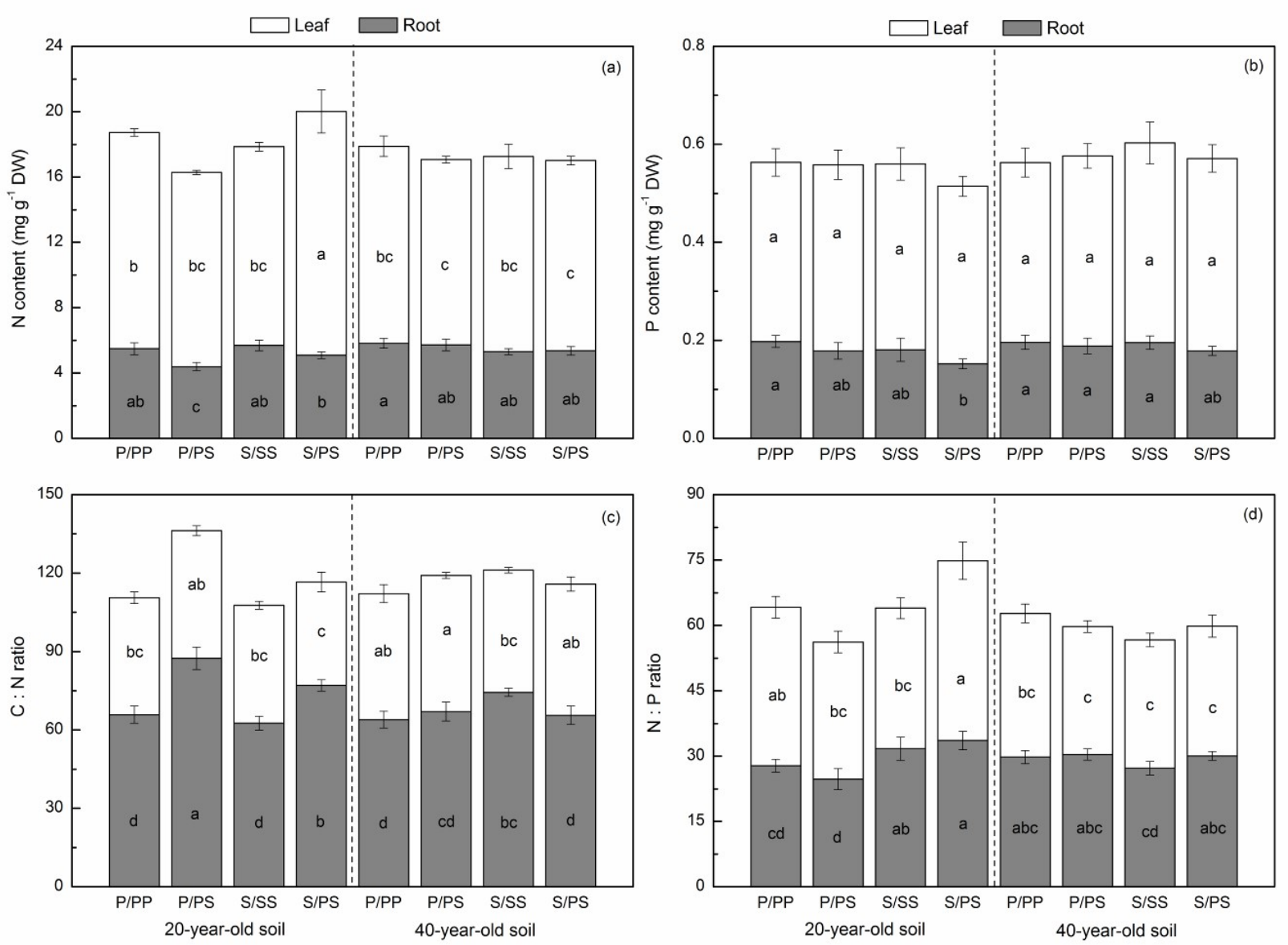
Figure 6.

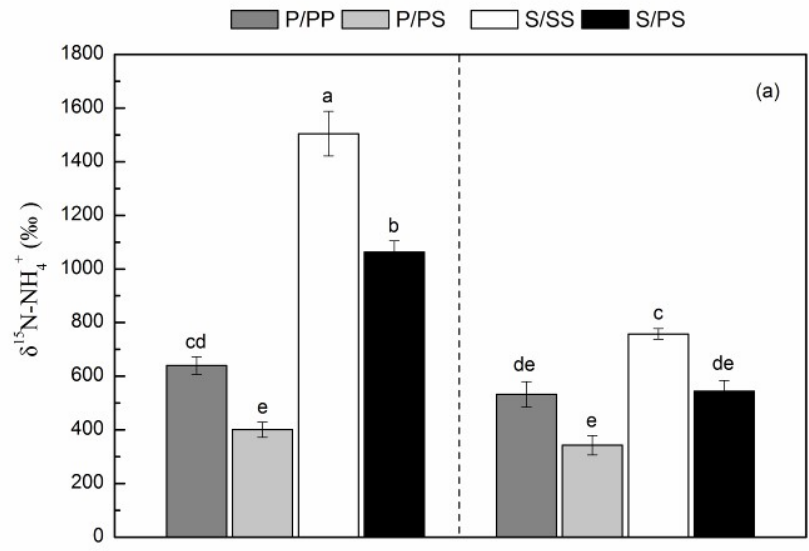

20-year-old soil

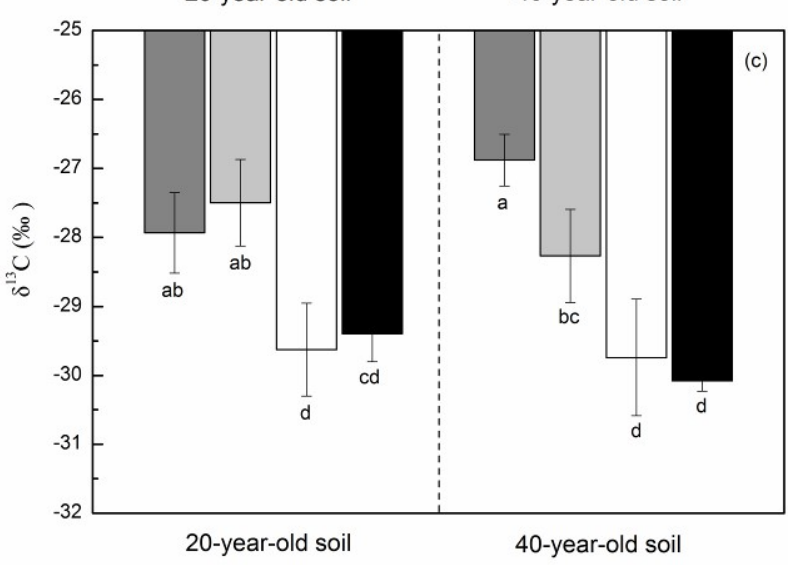

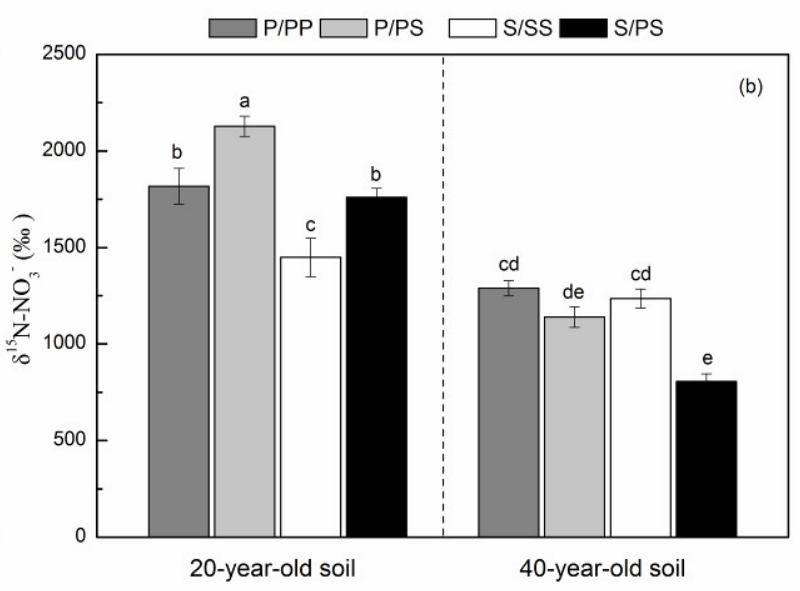

962

963 
Figure 7.

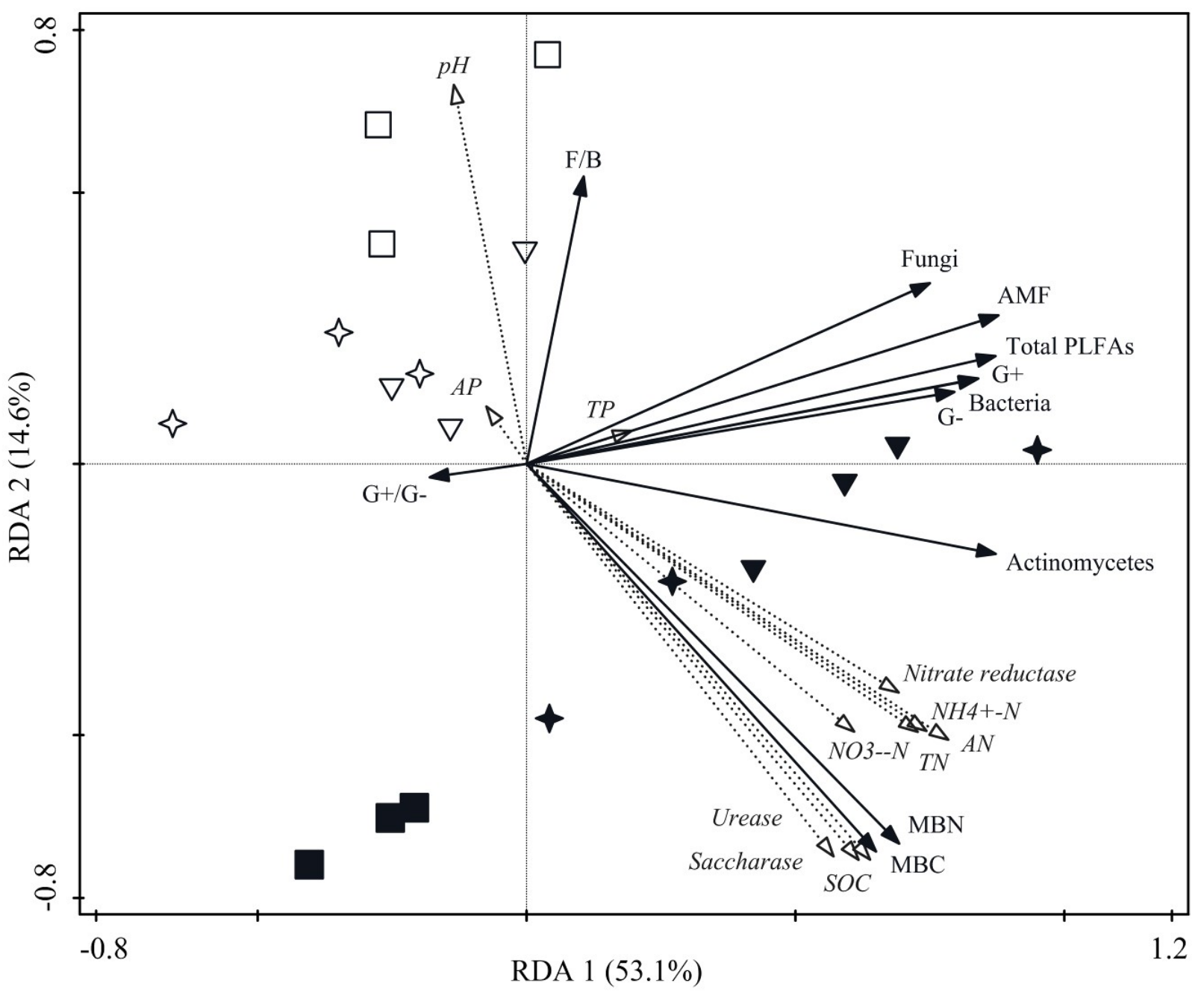


$967 \quad$ Figure 8.

(a)
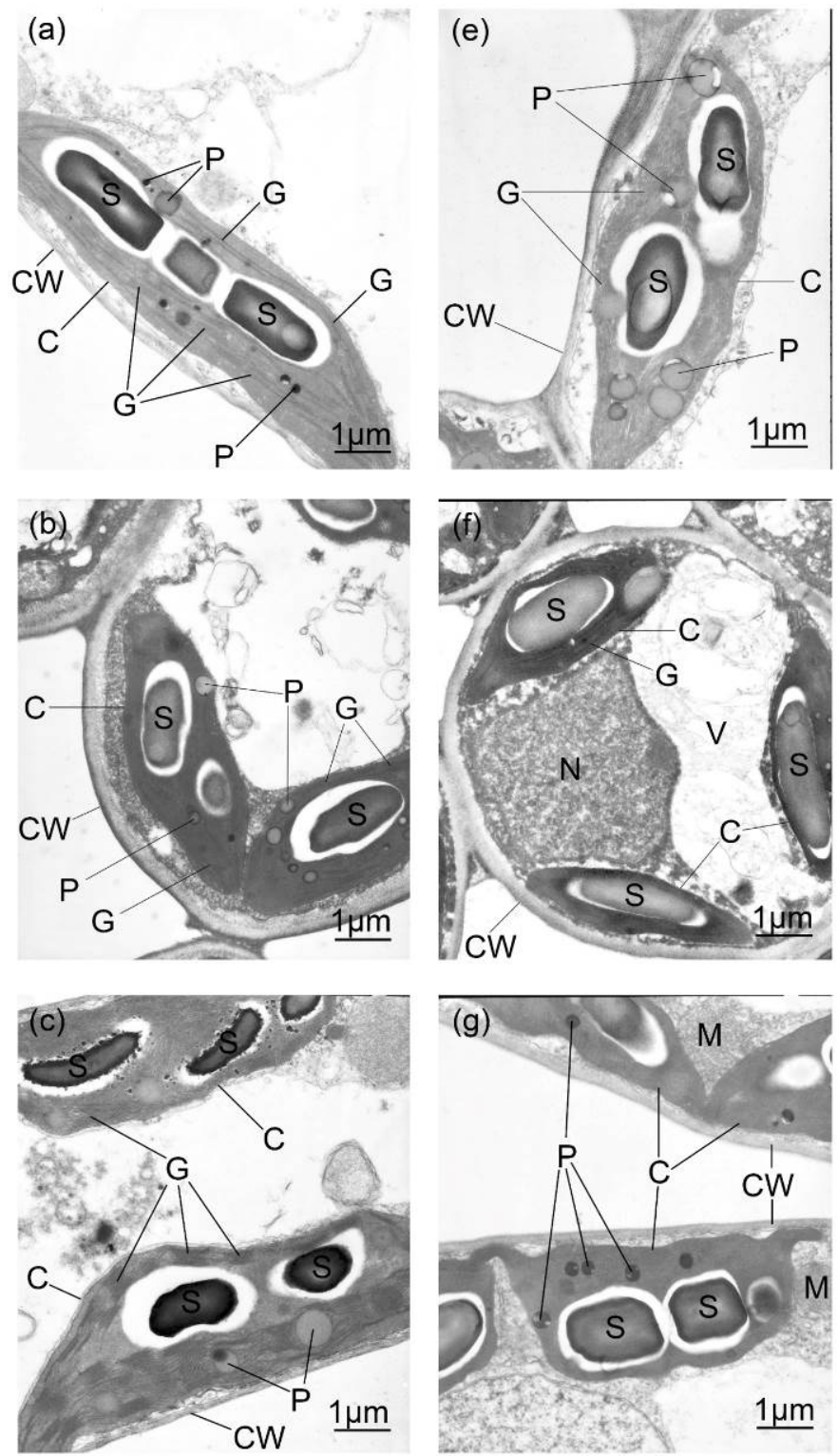

968
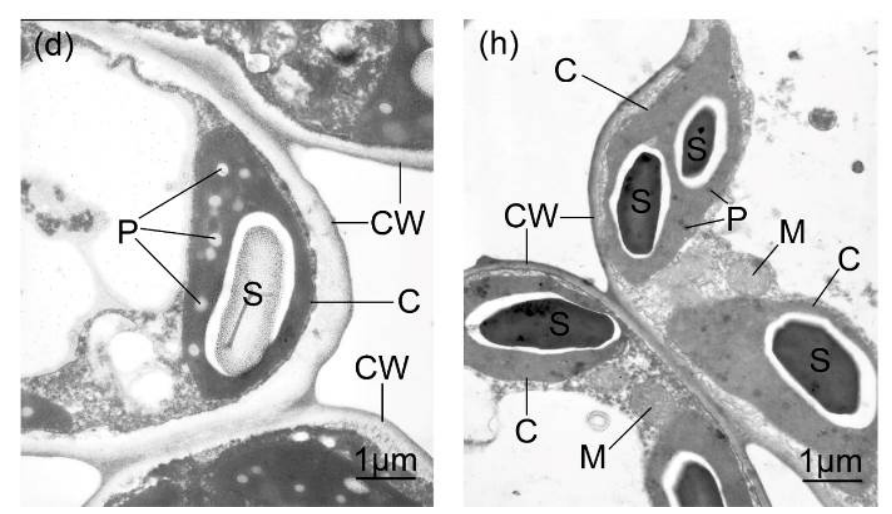